\title{
Bad Karma or Discrimination? Male-Female Wage Gaps among Salaried Workers in India
}

\author{
Ashwini Deshpande \\ Email: ashwini@econdse.org \\ Department of Economics \\ Delhi School of Economics
}

\section{Deepti Goel}

Email: deepti@econdse.org

Department of Economics

Delhi School of Economics

\section{Shantanu Khanna}

Email: shantanukhanna@gmail.com

(Revised Version, April 2016)

\section{Working Paper No. 243}

http://www.cdedse.org/working-paper-frameset.htm

\section{CENTRE FOR DEVELOPMENT ECONOMICS}

DELHI SCHOOL OF ECONOMICS 


\section{Introduction}

Satya Nadella, the CEO of Microsoft, in an interview in front of a prominent group of women IT professionals, said that women needed to trust "karma" if they don't get the pay raise they want. "It's not really about asking for a raise, but knowing and having faith that the system will give you the right raise". The statement was widely criticized, leading to a quick apology from Nadella, but it brought to the fore a fundamental question about how labour markets function, especially towards members of disadvantaged and marginalized groups. Should such individuals "have faith" and hope for their rewards to improve? If labour markets do not recognize and appropriately remunerate their worth, is it just a case of bad luck, or of labour market discrimination?

The problem is not simply one of pay raises, but more broadly one of gender parity in wages. Ironically, Nadella's statement came at a time when the White House officially recognized that the Equal Pay Act of $1963^{2}$ has a long way to go before gender parity in pay is achieved. The reality that full-time working women get $77 \%$ of their male counterparts' earnings prompted the executive order, issued in April 2014, by US President Barack Obama to prevent workplace discrimination and empower workers to take control over negotiations regarding their pay. In addition, he signed a Presidential memorandum that requires federal contractors to submit data on employee compensation by race and gender, helping employers take proactive efforts to ensure fair pay for their workers. There are numerous other examples from other countries of gender

\footnotetext{
${ }^{1}$ http://recode.net/2014/10/09/open-mouth-insert-foot-microsoft-ceo-tells-women-techies-to-trust-karma-on-pay-inequity/, accessed on $23^{\text {rd }}$ November 2014.

${ }^{2}$ This requires that men and women at the same workplace get equal pay for equal work.
} 
disparity in wages. In Britain, for instance, the supermarket chain ASDA faced mass legal action from thousands of female employees who claim they are underpaid compared to their male counterparts. ${ }^{3}$

This paper analyses the issue of gender parity in wages by focusing on the evolution of male-female wage gaps for an emerging economy, India, and decomposes the gaps to understand patterns of gender-based labour market discrimination. We use nationally representative data from the Employment-Unemployment Schedule (EUS) of two large rounds of the National Sample Survey (NSS) for 1999-2000 and 2009-2010, respectively in order to explore gender wage gaps among Regular Wage/Salaried (RWS) workers, not only at the mean, but along the entire distribution to see "what happens where". We then decompose the gaps into an "explained component" (due to gender differences in wage earning characteristics), and the "unexplained component" (due to gender differences in the labour market returns to characteristics); the literature treats the latter as a proxy for labour market discrimination. We perform the standard mean decomposition (using the Blinder-Oaxaca method, BO hereafter) and quantile decompositions (using Melly's refinement of the Machado-Mata decomposition method, MMM hereafter). We then evaluate changes in each of these over the ten-year time period. Our study presents the latest comprehensive empirical evidence on gender wage gaps and labour market discrimination in India. This is among the earliest studies of gender discrimination along the entire wage distribution for India and the first to focus on regular salaried workers, where jobs are presumed to be allocated on meritocratic lines.

Our main findings are as follows. There are significant gender gaps among RWS workers who constitute about $17 \%$ of the Indian labour force. The raw (unconditional) gender wage gap at the mean changes from 55 to $49 \%$ between $1999-2000$ and 2009-2010, but this change is not statistically significant. Over the ten-year period, the educational and occupational attainment of women improved relative to men, but in both years, average female wages were less than for males with similar characteristics. BO decompositions indicate that the bulk of the gender wage gap at the mean is unexplained, i.e. possibly discriminatory. While average

\footnotetext{
${ }^{3}$ http://asda.payjustice.co.uk/asda-campaign/, and http://www.theguardian.com/business/2014/oct/24/asda-mass-legal-actionequal-pay, accessed on $31^{\text {st }}$ October 2014;
} 
characteristics for women improved over the decade, the discriminatory component of the wage gap also increased. In fact, in 2009-2010, if women were paid like men, they would have earned more than men on account of their superior characteristics.

Moving beyond the mean, for both years, male wages are higher than female wages across the entire wage distribution. In both years, the gender wage gaps are higher at lower deciles and decline thereafter. In 2009-2010, the gap is highest at the first decile at 105\%, and it declines to about $10 \%$ at the ninth decile. Thus, we see the existence of the "sticky floor", in that gender wage gaps are higher at lower ends of the distribution and steadily decline over the distribution. This is true for all RWS worker, as well as separately for rural and urban workers. Using standard definitions, we find that the sticky floor became "stickier" for RWS women over the decade. Like the BO decomposition, the MMM decompositions also reveal that bulk of the gender wage gaps are discriminatory, and that the discriminatory component is higher at lower ends of the distribution.

The rest of this paper is organized thus. Section 2 contains a review of the literature; Section 3 explains the decomposition technique; Section 4 describes the data and presents gender differences in characteristics; Section 5 contains the regression and decomposition results; Section 6 discusses the findings in the larger context of gender discrimination and Section 7 offers concluding comments.

\section{A Brief Review of the Literature}

The overall literature on gender discrimination in India is vast, and covers a very broad array of disciplines and methodologies. Since our study is empirical and focused on the labour market, we refer to the relevant literature here.

2.1 Measuring and Understanding Participation Rates 
An important issue that precedes the discussion on women's involvement in productive work is the question of its measurement. Women's participation in economic activities is typically underestimated, as women themselves internalize the under-valuation and low worth that society places on their work. Thus, in most surveys, in response to questions such as, "In addition to household work, do you work outside the home?" several women misreport or under-report their participation in productive work. Underreporting also occurs because women's participation in productive work is often unpaid (see, for instance, Chaudhary and Verick 2014; Deshpande 2011 for a discussion of underreporting). This underreporting is likely to be lower for women working in RWS jobs, as this is paid work, and often outside the home.

For India, gender differences in labour force participation rates (LFPRs), with a focus on the persistently low levels of female LFPRs have been analysed extensively (e.g. Chaudhary and Verick 2014; Mukhopadhyay and Tendulkar 2006, among others). Klasen and Pieters (2015) study the stagnation in female LFPRs in urban India between 1987 and 2009, which hovers around 18\% over the period, despite increases in education and wage levels, rising growth and fertility decline. They find that on the supply side, rising household incomes, husband's education, stigmas against educated women engaging in manual work; and on the demand side, insufficient growth of jobs suitable for educated women are the main factors contributing to a lack of increase in participation rates of urban Indian women. In an earlier study, (Klasen and Pieters 2012), they suggest that drivers of labour force participation for women with low education are different from those for more educated women. For the former, they find that LFPRs are driven more by necessity than by improved opportunities. On the other hand, highly educated women are more likely to work in better paying jobs, and thus their participation is a positive function of their education, and expected wages.

\subsection{Wage Gaps}

\subsubsection{Understanding Gender Wage Gaps}


In addition to clear and persistent differences in labour force participation rates, data reveal sharp gender wage gaps, the latter consistent with international experience. Mahajan and Ramaswami (2015) investigate the apparent paradox that gender wage gaps in agricultural wages are higher in south India, a region with more favorable indicators for women, compared to north India. They investigate whether this could be due to Esther Boserup's proposition, viz., that higher gender gaps in the south are due to higher female LFPRs in that region (Boserup 1970). They find that differences in female labour supply are able to explain about $55 \%$ of the gender wage gap between the northern and southern states of India. Their paper highlights the importance of looking at LFPR as a determinant of gender wage gaps. However, this analysis would require a separate paper. Therefore, we take LFPRs as given, and conditional on participation analyse gender wage gaps.

Formal sector, urban labour markets, presumably more meritocratic, are not immune to gender wage differences either. Deshpande and Deshpande (1997) is an early overview study that compares summary statistics drawn from various NSS reports. Varkkey and Korde (2013) document gender pay gaps using paycheck data between 2006 and 2013 for 21,552 respondents, of which $84 \%$ were males. This data is based on a voluntary internet survey conducted among formal sector workers, and hence, the sample is not representative. They find that the pay gap increased with skill level and position in the occupational hierarchy. ${ }^{4}$ Duraisamy and Duraisamy (2005) use least squares as well as quantile regressions on NSS data for 1993-1994 to examine gender differences in wage premia associated with various educational categories across states.

\subsubsection{Decomposing Average Gender Wage Gaps}

The entire raw gender wage gap might not be due to discrimination in the labour market. The decomposition of wage/earnings gaps into the "explained" and the "unexplained" components has been widely used in order to tease out the effect of discrimination. In India, the BO decomposition method (Blinder 1973;

\footnotetext{
${ }^{4}$ These findings are at variance with our findings of a sticky floor. This is perhaps because their sample is not representative and is restricted to internet users. Also their educational categories are not comparable to ours.
} 
Oaxaca 1973) has been used to decompose average wage and earnings gaps by caste (Banerjee and Knight 1985; Deshpande and Ramachandran 2014; Deshpande and Sharma 2016; Madheswaran and Attewell 2007, among others) and religion (Bhaumik and Chakrabarty 2009).

There are a only a handful of studies that decompose average gender wage gaps in India; with only a couple of studies examining gender gaps at the all India level, and changes therein over time. ${ }^{5}$

Madheswaran and Khasnobis (2007) and Mukherjee and Majumder (2011) are national studies. The former uses the standard BO methodology, as well as its various refinements, and the latter examines "earning disparity" using the Theil Index, "occupation disparity" using the segregation index, "occupation choice" using a multinomial logit model, and estimates Mincerian wage equations, with decompositions for the latter two. Both these studies differ from our paper in terms of the time period, or in types of workers considered, but both point to an increase in the discriminatory component of the average gender wage gap, a finding similar to ours.

\subsubsection{Sticky Floor or Glass Ceiling: What happens Where?}

We use Melly's refinement of the Machado-Mata (MM) methodology in order to decompose the gender wage gaps at each quantile of the earnings distribution. This methodology, based on quantile regressions (Koenker and Bassett 1978), has been used to analyse gender wage gaps in one earlier study (Agarwal, 2013).

Studies that decompose gender wage gaps along the entire wage distribution raise an important issue within the gender discrimination literature: do women face a "glass ceiling" or a "sticky floor"? For instance, papers (such as Albrecht et al. 2003; Arulampalam et al. 2007; De la Rica et al. 2008) show that in several

\footnotetext{
${ }^{5}$ Studies focusing on a few states include Duraisamy and Duraisamy (1999) and Kingdon and Unni (2001).
} 
developed European countries, women face a glass ceiling, i.e. the gender wage gap is higher at the higher quantiles, with a sharp acceleration at the upper tail of the distribution. However, developing countries such as China (Chi and Li 2008), along with European countries such as Spain (Arulampalam et al. 2007), are characterized by a "sticky floor". These terms are used to describe both the raw wage gaps, as well as the unexplained or discriminatory part of the gap in general discussions. Arulampalam et al (2007) define a "glass ceiling" as existing if the $90^{\text {th }}$ percentile wage gap is higher than the wage gap at all other parts of the wage distribution by at least two percentage points. Similarly, they define a "sticky floor" when the wage gap at the $10^{\text {th }}$ percentile is higher than that at the $25^{\text {th }}$ percentile by at least two percentage points. An alternate weaker definition would be to maintain the 2 percentage points criterion, but compare the $10^{\text {th }}$ and the $50^{\text {th }}$ percentile instead. These definitions have become fairly popular in the literature and are used in several papers as a rough rule to establish the presence of a sticky floor. Whereas Agarwal (2013) finds a glass ceiling overall, with urban women facing a sticky floor and rural women a glass ceiling, our results show that using both these definitions women in the RWS sector in India face a sticky floor, not a glass ceiling, and this result holds for all workers, as well as separately for rural and urban workers. The reason for this difference in results could be that we are focusing exclusively on RWS workers, (for reasons explained in the introduction), whereas Agarwal presumably is focusing on all workers (the paper does not specify if he is using a subset or all workers for whom wage data is available). The majority of RWS workers are urban (65\% in 2009-10). Additionally, both the data set and the time period of the Agarwal study are different from ours.

\section{Methodology}

The BO methodology, which involves decomposing the average wage gap, is well-known. Quantile Regression decomposition methods are a generalization of the mean decomposition for the entire distribution. There are several such methods in the literature. ${ }^{6}$

\footnotetext{
${ }^{6} \mathrm{MM}$ is only one of the methodologies for decomposition of gaps along the entire distribution. Hnatkovska et al. (2012) use an alternative methodology, viz., reweighted influence function, or RIF regressions (Firpo et al. 2009), and decompositions based on these to study wage differentials between castes over the period 1983-2005 using four rounds of NSS data.
} 


\subsection{Melly-Machado-Mata Method}

The Machado Mata (MM) methodology (Machado and Mata 2005) estimates the entire distribution using conditional quantile regressions. The four steps of the MM procedure to generate a counterfactual log wage distribution are:

1) Generate a random sample of size $n$ from a uniform distribution $U[0,1]: u_{1}, u_{2} \ldots, u_{n}$

2) For men and women separately, estimate $n$ QRs using the draw values as the quantile value at which to estimate the QRs. Thus, we get two sets of vectors, $\left\{\hat{\beta}_{u_{j}}^{m}\right\}_{j=1}^{n}$ and $\left\{\widehat{\beta}_{u_{j}}^{f}\right\}_{j=1}^{n}, n$ for men and $n$ for women.

3) Draw a random sample of size $n$, with replacement, from the covariate distribution of men and women separately. Denote these two sets of $n$ vectors by $\left\{\tilde{X}_{j}^{m}\right\}_{j=1}^{n}$ and $\left\{\tilde{X}_{j}^{f}\right\}_{j=1}^{n}$

4) Finally, two counterfactual distributions are estimated as $\left\{Y_{j}^{c f}=\tilde{X}_{j}^{m} \widehat{\beta}_{u_{j}}^{f}\right\}$ or as $\left\{Y_{j}^{c m}=\right.$ $\left.\tilde{X}_{j}^{f} \widehat{\beta}_{u_{j}}^{m}\right\}$, for $j=1,2 \ldots, n$.

The first counterfactual distribution represents the distribution of log wages of men if they are paid according to the female wage structure, while the second counterfactual represents the distribution of log wages of women if they were to be "paid like men".

At the $\theta^{\text {th }}$ quantile, the difference between the estimated unconditional quantile of log wage for men, $\widehat{Q^{m}}(\theta)$, and the estimated unconditional quantile of log wage for women, $\widehat{Q^{f}}(\theta)$, can be decomposed in two alternate ways,

$$
\begin{aligned}
& \widehat{Q^{m}}(\theta)-\widehat{Q^{f}}(\theta)=\underbrace{\left[\widehat{Q^{m}}(\theta)-\widehat{Q^{c f}}(\theta)\right]}_{\text {Effects of Coefficients }}+\underbrace{\left[\widehat{Q^{c f}}(\theta)-\widehat{Q^{f}}(\theta)\right]}_{\text {Effects of Characteristics }} \\
& \widehat{Q^{m}}(\theta)-\widehat{Q^{f}}(\theta)=\underbrace{\left[\widehat{Q^{m}}(\theta)-\widehat{Q^{c m}}(\theta)\right]}_{\text {Effects of Characteristics }}+\underbrace{\left[\widehat{Q^{c m}}(\theta)-\widehat{Q^{f}}(\theta)\right]}_{\text {Effects of Coefficients }}
\end{aligned}
$$


where $\widehat{Q^{c f}}(\theta)$ is the estimated counterfactual unconditional quantile of log wage for men created using the coefficients of women and $\widehat{Q^{c m}}(\theta)$ is the estimated counterfactual unconditional quantile of log wage for women created using the coefficients of men.

Melly's (2006) procedure is numerically equivalent to the MM procedure described above. Unlike the MM procedure that relies on a random draw of $n$ vectors from the distribution of covariates, the MMM uses all observations on covariates and combines with each observation the $n$ quantile regression coefficients to generate the unconditional (marginal) distribution of log wages. Estimating the unconditional distribution this way has the advantage of using all the information contained in the regressors. This makes the MMM estimator more efficient than the MM estimator.

\section{Data and Descriptive Statistics}

We use data from the $55^{\text {th }}$ and $66^{\text {th }}$ rounds of NSS-EUS for the years 1999-2000 and 2009-2010 respectively. The EUS provides wage information for both casual labourers (CL) and regular wage/ salaried (RWS) workers. NSS defines RWS workers as those who worked in others' farm or non-farm enterprises and received salary or wages on a regular basis (as opposed to the daily or periodic renewal of work contracts). We focus on RWS workers because for the most part, they are in formal sector jobs that are presumed to be meritocratic, as well as governed by regulations that do not sanction discrimination. It is therefore more interesting (and troubling) if we find evidence of labour market discrimination among RWS workers. Furthermore, the link between characteristics such as education and wages is likely to be tenuous for CL, given that CL are mainly employed in unskilled manual work. Thus, wage decompositions for RWS workers are likely to give a more accurate picture of discrimination. 
Our sample consists of full-time RWS workers between the ages 15 and $59 .{ }^{7}$ We calculate daily wage rates by dividing the total weekly earnings by the total days worked in that week. ${ }^{8}$ Nominal wage rates are converted into real terms (1999-2000 prices) using separate state level deflators for urban and rural areas. ${ }^{9}$ Finally, we trim the sample at the two ends, removing the top and bottom $0.05 \%$ of the wage distribution in order to remove outliers and possible data entry errors. We are left with 34,131 observations for 1999-2000 and 33,676 observations for 2009-2010.

\subsection{Labour Force Participation}

Between 1999-2000 and 2009-2010, LFPRs for both men and women have declined: from 86 to $83 \%$ for men, and from 33 to $28 \%$ for women. ${ }^{10}$ Could the declining female LFPRs indicate that India is on its way to displaying the presumed U-shaped relationship between economic growth and female LFPRs? The evidence for the U-shaped relationship is widely debated, and in fact, individual countries display a great deal of heterogeneity in the relationship between economic growth and LFPRs. For India, there is no evidence of the U-shape relationship yet (Chaudhary and Verick 2014). The persistence of low female LFPRs by international standards ${ }^{11}$ in the context of high growth is both a theoretical and empirical puzzle, the analysis of which is beyond the scope of this paper.

Table 1 gives the breakup of labour force into four mutually exclusive work categories. In both years, majority of women in the labour force are either casual labourers or are self-employed, with these two categories comprising about $84 \%$ of women in 2009-2010. In both years, a larger share of women work as

\footnotetext{
${ }^{7}$ To be sure that we captured only RWS workers, we only considered those individuals who reported RWS to be their principal activity in the week preceding the survey.

${ }^{8}$ EUS allows an individual to report multiple jobs during a week. However, overwhelming majority of RWS workers (above $98 \%$ in both years) report being involved in only one activity. We restrict our analysis to these workers and calculate the wage rate using this single activity that they are involved in.

${ }^{9}$ For urban areas we use the Consumer Price Index for Industrial Workers (CPI-IW) and for rural areas we use the Consumer Price Index for Agricultural Labor (CPI-AL).

${ }^{10} \mathrm{We}$ have tested for the statistical significance of all results in this section. We use a test of difference in proportions when comparing within year gender differences in shares, and an OLS wage equation with a gender dummy when looking at within year gender wage gaps. Additionally, we use a Difference-in-Differences specification (interaction of gender and year dummies) when examining whether the changes over the decade were significantly different for men and women.

${ }^{11}$ Globally, female LFPRs have remained stable over 1990-2010 at roughly 52\%. This average conceals a great deal of regional heterogeneity: Female LFPRs vary between around 33\% in North Africa, West and South Asia; and 66\% in East Asia and subSaharan Africa. Global male LFPRs have declined over this period from 81 to $77 \%$, reflecting an increase in educational enrolment rate among younger men (ILO, 2014)
} 
casual labourers compared to corresponding shares for men, and a smaller share work as RWS workers. The change over the decade shows that the RWS share among men and women has increased, from 18.1 to $18.7 \%$ for men), and to a larger extent, from 9.3 to $12.7 \%$ for women, resulting in a decline in the gender difference in RWS shares over the decade.

\subsection{Regular Wage Salaried (RWS) Employment}

RWS workers constitute about $17 \%$ of the labour force. Among all RWS workers, over the ten-year period, there has been a small, albeit statistically significant, increase in the proportion of women (from 15.8 to $17.8 \%$ ), and a corresponding decrease in the proportion of men (from 84.2 to $82.2 \%$ ). However, men continue to get the overwhelming share of RWS jobs.

The gender wage gap among RWS workers is substantial in both years. The (raw/unconditional) gender wage gap at the mean is $55 \%$ in $1999-2000$ and it is $49 \%$ in $2009-2010 .{ }^{12}$ This change over the decade is not statistically significant. In both years, the gap is substantially higher at the first decile compared to the median and the ninth decile, even though there is a significant decline in the gender wage gap at the median from 76 to 53\%. At all points in the wage distribution, male wages are higher than female wages. Figure 1 shows the gender wage gaps for both years at the mean and across percentiles. We see that in both years, the gaps are higher at lower end of the wage distribution and decline, across the distribution, revealing the "sticky floor". For most percentiles between the $15^{\text {th }}$ to the median, gaps have declined over the decade, whereas they have mostly increased between the $70^{\text {th }}$ to $80^{\text {th }}$ percentiles. For 2009-2010, the unconditional log wage gap at the $10^{\text {th }}$ percentile is 0.72 , whereas the gap at the $25^{\text {th }}$ percentile is 0.52 . This is a 20 percentage point difference, far greater than the 2 percentage point difference used in the literature to establish the sticky floor. The difference between log wage gaps at the $10^{\text {th }}$ percentile and the $50^{\text {th }}$ percentile is even greater $(29$ percentage points). For 1999-2000, the gender gap is the same for the $10^{\text {th }}$ and the $25^{\text {th }}$ percentile $(0.69)$.

\footnotetext{
${ }^{12}$ Gender wage gap at the mean is defined as the difference between the arithmetic means of logarithm of wages of men and women and is mathematically equivalent to $\log \left(\frac{G M_{\text {men }}}{G M_{\text {women }}}\right)$ where GM refers to the geometric mean for that group. Throughout the paper, the gender wage gap at the mean expressed in percentage refers to $\frac{G M_{m e n}-G M_{\text {women }}}{G M_{\text {women }}} * 100$.
} 
However, the gap between the $10^{\text {th }}$ and $50^{\text {th }}$ percentile is 13 percentage points. Hence, even in $1999-2000$, gender gaps were characterized by a sticky floor using the alternate weaker definition. Therefore, the sticky floor has become "stickier" for RWS women over this ten year period.

\subsection{Gender Differences in Characteristics}

There are several factors that might account for these gender wage gaps within RWS workers. Men and women could differ in terms of their observable characteristics such as age; urban or rural residence; educational attainment; occupation and industry of employment; type of job such as public sector versus private sector, temporary versus permanent, unionized versus non-unionised; their social groups such as caste and religion; and their region of residence (geographical location within the country). We have examined each of these factors separately ${ }^{13}$; here, some key factors are summarised.

In 2009-2010, the average RWS worker was 35.6 years old. In both years, men are older than women by about a year. While age is used as a proxy for experience, we should note that women often drop out of jobs during childbearing years and resume after a few years, so they might have lower experience than men of the same age who would have been working continuously.

\subsubsection{Educational Attainment}

Table 2 shows that the proportion of illiterates and of "graduates and above" is higher among women than among men for both years. In 2009-2010, $43 \%$ of female RWS workers had at least a graduate degree, compared to only $34 \%$ for males. Not only is the share of women in the highest educational category greater than that of men, it records a larger increase over the decade (16 percentage points for women) compared to

\footnotetext{
13 All the results are available with the authors upon request.
} 
men (11 percentage points for men). The decline in the share of illiterates is also greater for women $(7.5$ percentage points) compared to men (3.4 percentage points). Thus, over the decade, the educational attainment of women has improved relative to men.

Table 2 also shows that, for both years, gender wage gaps exist within each category of education. Similar to the sticky floor phenomenon, gender wage gaps are much higher at the lower end than at the higher end of the educational spectrum. Gender wage gaps did not change significantly over the decade for any of the education categories except for secondary and higher secondary education. For this category, the gap increased from 38 to $63 \%$ over the period.

\subsubsection{Occupational and Industrial Distribution}

There are clear gender differences in occupational distribution in both years. ${ }^{14}$ 'Professionals and Associate Professionals' (representing the higher end of the earning spectrum) form the largest occupational category for women in both years, employing close to $45 \%$ of all RWS women. The share of women in this category is over 17 and 22 percentage points more than the corresponding share for men in 1999-2000 and 2009-2010, respectively. In the category 'Craftsmen and Machine Operators', the male proportion is 17 and 23 percentage points more than the corresponding female proportion in 1990-2000 and 2009-2010, respectively.

There exists a gender wage gap in almost all categories of occupation. ${ }^{15}$ At the lower end of the occupational spectrum, viz., Labourers and Unskilled Workers, wage differentials increased from 62 to $93 \%$, while for Craftsmen and Machine Operators the gap decreased from 140 to $93 \%$ over the period.

\footnotetext{
${ }^{14}$ Workers are divided into seven occupational categories that correspond roughly to the NCO 2004 one-digit occupational classification used in 2009-2010. Two different occupation classification systems have been used for the $55^{\text {th }}$ and $66^{\text {th }}$ rounds of the NSS: these are NCO 1968 and NCO 2004, respectively. We created our own concordance to arrive at the seven broad occupational categories used in this paper.

${ }^{15}$ Except for 'Administrators and Managers' in both years and for 'Skilled Agriculture and Fishery workers', and 'Clerks and Related workers' in 1999-2000.
} 
Examining the gender differences using a seven-fold division of industries, we find that for both years, the proportions of men are significantly different from women in all industries.

\subsubsection{Public/ Private Sector, Union Membership, and Permanent/Temporary Jobs}

Table 3 shows that the proportion of all RWS workers in the public sector has gone down over the decade from 37 to $34 \%$. In both years, a higher share of RWS women are in public sector jobs compared to RWS men. Over the ten year period, the share of private sector jobs among RWS men rose from about $64 \%$ in $1999-2000$ to $68 \%$ in $2009-2010$, whereas for women the change was minimal. In both years, within each sector, women are, on average, paid less than men. Notably, whereas the gender wage gap increased in the public sector (from $43 \%$ in 1999-2000 to 69 in 2009-2010) it decreased in the private sector (from $68 \%$ in 1999-2000 to 52 in 2009-2010).

Among RWS workers, the proportion of union members declined by 13 percentage points over the decade reflecting global trends. However, the share of unionized men and women is not different from each other, which is an interesting feature of the Indian labour market. In both years, average wages of women within both members and non-members are significantly less than that for men. The gender wage gap declined significantly for union members over the decade.

A similar analysis of permanent or temporary work status reveals that overall, the share of permanent workers has gone down over the decade from roughly 73 to $68 \%$. The share of permanent workers is no different between men and women. Women are paid less than men within both the permanent and temporary categories. It is also interesting to note that the gender wage gaps declined significantly among temporary workers, but not among permanent workers.

\subsubsection{Caste and Religion}


Indian society is marked by multiple cleavages, caste being another critical axis of differentiation and disadvantage. The overlap of gender and caste introduces a new complex dimension in overall disparities, in that restrictions on women's work outside the home, and on their public visibility have historically been greater among higher-ranked castes.

While a detailed assessment of the gender-caste overlap is outside the scope of this paper, ${ }^{16}$ we discuss some salient factors in the context of RWS employees. Data on caste are available by broad administrative categories: Scheduled Castes (SC), Scheduled Tribes (ST) and Other Backward Classes (OBC) - groups of castes, tribes and communities identified as beneficiaries of affirmative action due to accumulated disadvantage, and in the case of SCs and STs added stigmatization on account of their caste/tribe status. Those who are not eligible form a heterogeneous residual category of "Others" (everyone else), a rough proxy for Upper Castes (UC). ${ }^{17}$

From Table 4 we note that the proportion of UC RWS workers has decreased from 50.3 to 42.8 . This decrease is mirrored in the rise in the proportion of OBC workers from 29.4 to 35.3 and in SC workers from 14.9 to $16.9 \%$.

There are gender wage gaps within all caste categories. There is a significant decrease in the gender wage gap for OBCs over the decade. For other caste categories, gender wage gaps did not change significantly over time. SC women are likely to be concentrated at the lower end of the wage distribution and could possibly account for a large part of the sticky floor.

\footnotetext{
${ }^{16}$ See Deshpande (2007) and (2011) for a discussion of the gender-caste overlap.

17 The "Others" group includes, but is not confined to, the Hindu upper-castes; however, it can be taken as a rough proxy for the latter. NSS data does not allow us to isolate Hindu upper castes. Note that this four-way division understates the gaps between the Hindu upper castes and the most marginalized SCs and STs.
} 
Hindus form the largest proportion of RWS (83\% in both years), reflecting their share in the population. In both years, the share of Muslims among RWS men is greater than their share among RWS women (in 2009-10, for men 10.2\% and for women 5.6), while the opposite is true for Christians (3.0\% for men and $6.7 \%$ for women).Gender wage gaps for Hindus, Muslims and Christians are significant for both years.

\section{Results}

In this section, we first present the estimates for the gender wage gap at the mean (using OLS) and at several quantiles (using quantile regressions), conditioning for observable characteristics. Gender wage gap estimates based on two different regression specifications, namely partial and full, are presented. In the partial specification, log wages are regressed on only exogenous variables, viz., age, age squared, caste dummies, married, education dummies, urban residence and regions; while in the full specification, additional controls for public sector, union membership, permanent job, occupation and industry are also included.

\subsection{OLS Results}

Table 5 shows the OLS results for the pooled sample, and separately for men and women. The regression on the pooled sample includes a male dummy which is the main variable of interest. It captures the gender wage gap conditional on observable characteristics while assuming that the returns to these characteristics are the same for men and women. The top panel of Table 5 shows that, in both years, gender wage gaps exist even after accounting for differences in characteristics. For the partial specifications, in 19992000 the gender wage gap at the mean is $39 \%$, and in $2009-2010$ it is $46 \%$.

Interestingly, when we move from the partial to the full specification, the gender gaps increase to $45 \%$ and 54\% in 1999-2000 and 2009-2010, respectively. This suggests that RWS women have better job characteristics compared to men in terms of the types of jobs, and the occupation and industry of employment. 
Separate regressions for men and women reveal that the labour market rewards the same characteristics very differently for men and women. The full specification for 2009-2010 shows that the coefficients of all the education variables are larger for women than for men, indicating that being educated has higher returns for women than men. Also, union membership has a stronger positive effect on female wages than male wages.

\subsection{Estimates from Quantile Regressions}

Table 6 presents the gender wage gaps and returns to characteristics at the first, third, fifth (median), seventh and ninth deciles for the full specification. The first panel using the pooled sample shows that gender wage gaps exists at all quantiles, even after conditioning for observable characteristics. Notably, moving from lower to higher quantiles, the gender wage gaps decrease: $87.8 \%$ at the first decile, which decreases to 39.8 at the ninth decile ${ }^{18}$.

We find that the gaps at the upper deciles (seventh and ninth) increase as we move from the partial to the full specification. This suggests that RWS women at the higher ends of the conditional distribution are in better jobs in terms of the type of job, occupation and industry.

Finally, separate regressions for men and women reveal that, relative to being illiterate, the returns to the highest category of education, i.e. graduate and above seem larger at the first and second deciles compared to the seventh and ninth. For women, we notice that the return to being married is positive and significant at the bottom of the distribution, but is negative and significant for the top three deciles. For men, the return is positive and significant at all deciles, and declines at higher deciles.

\footnotetext{
18 Separate results for rural and urban workers, which show the same pattern of declining gaps moving from lower to higher quantiles, are available from the authors upon request.
} 


\subsection{Decomposition Results}

\subsubsection{Blinder-Oaxaca Decomposition}

We decompose the gender wage gap at the mean using three counterfactual wage structures- the male wage structure, the female wage structure and the pooled wage structure. Table 7 presents the BO decomposition results for the two years using the full specification.

In both years, the overwhelming part of the male-female wage gap at the mean is unexplained. In 19992000 , using the male, female and pooled wage structures as the counterfactuals, 92,78 and $88 \%$ of the wage gap respectively, was unexplained. The corresponding shares for 2009-2010 are 119, 89 and $111 \%$, respectively, indicating an increase in the unexplained component, suggesting that wage discrimination against women increased over this period. Interestingly, in 2009-2010, using the male and the pooled wage structures as counterfactuals, the unexplained part of the wage gap is larger than the total wage gap itself (it is greater than $100 \%$ ). This implies that if the labour market rate of compensation was the same across gender, women would have earned, on average, a higher wage than men given their superior characteristics. Compared to 2009-2010, the explained component in 1999-2000 is smaller (for all three counterfactuals), indicating that over the decade the average characteristics of women in RWS employment improved relative to men.

\subsubsection{Decomposition}

Figures 2 and 3 and Table 8 present the overall gender wage gap, and its decomposition into the explained and the unexplained components for each percentile for the two years. ${ }^{19}$ Similar to the BO

\footnotetext{
${ }^{19} \mathrm{We}$ also present the $95 \%$ confidence intervals (dashed lines) for each of these components based on bootstrapped standard errors.
} 
decomposition at the mean, we note that the overwhelming part of the overall gender wage gap across most percentiles is unexplained or discriminatory (in both figures, the unexplained component closely tracks the overall wage gap).

Figure 2 shows that in 1999-2000, beyond the first decile, the explained component is insignificant throughout, while both the overall gender wage gap and the unexplained component are significant throughout. ${ }^{20}$ Thus, in 1999-2000, if women were 'paid like men', i.e. if they faced the same labour market returns to characteristics as men did, we would not see a wage gap between men and women beyond the first decile. Figure 3 shows that in 2009-2010, the overall gender wage gap and the unexplained component remain significant over the entire distribution. However, unlike 1999-2000, the explained component is negative and significant beyond the third decile. This means that beyond the third decile, if women in RWS were "paid like men', they would have earned a higher wage than men due to better characteristics than the men.

Both figures also show that the overall gender wage gap as well as the unexplained component get smaller as we move from lower to higher percentiles. Thus, the discriminatory component of the gender wage gap also follows a sticky floor, revealing that women at the lower end of the distribution face greater discrimination. In both figures, juxtaposing the MMM decomposition on to the $\mathrm{BO}$ decomposition, we see that the unexplained part of the BO decomposition cuts the downward sloping curve for the unexplained part of the MMM decomposition roughly at the middle.

\section{Discussion}

We focus on the most recent decade, as this has been a period of rapid growth, new job openings, greater integration with the global economy, and increasing domestic privatization in India. While this paper is not a causal analysis of these changes on gender wage gaps and gender discrimination, it raises questions

\footnotetext{
20 The unexplained component is insignificant only for the top two percentiles.
} 
about the likely association between these structural changes and wage disparities, and more broadly about discrimination. Seguino (2000), in a cross-country study, finds that gender inequality, which lowers women's wages relative to men's, is actually a stimulus to growth in export oriented economies. This runs counter to the conventional wisdom that greater inequality (based on household income as a unit of measurement, obliterating gender gaps) is inimical to growth because it fuels social conflict. Seguino suggests that inequality is "less likely to produce social conflict if the burden is borne by women, a group traditionally socialized to accept gender inequality as a socially acceptable outcome” (p. 1212)

In India, we note that high growth has not been accompanied by an increase in female LFPRs. Also, in 2009-2010, only about $10 \%$ of women in the labour force are in RWS jobs (as opposed to $16 \%$ for men), and the overwhelming share of RWS jobs are held by men (83\%). Equally, if not more, worrying is the fact that women face adverse returns to their characteristics. In 2009-2010, throughout the wage distribution, although women have better characteristics than men, they earn less than men due to labour market discrimination. Moreover, at the lower end of the wage distribution, for the bottom $10 \%$ where women face higher discrimination, the wage gaps have increased (Fig. 1).

\subsection{The Sticky Floor}

A major contribution of our paper has been to highlight the sticky floor phenomenon in the gender wage gaps picture for India. Recent studies on China (Chi and Li 2007), Thailand (Fang and Sakellariou 2010), Sri Lanka (Gunewardena 2008), Vietnam (Pham and Reilly 2007) and the Philippines (Sakellariou 2004) find a sticky floor effect for all these countries as well. This is in contrast to the glass ceiling that is observed in several developed countries.

Our study finds that the magnitudes of log wage gaps, at the mean and across quantiles, are much larger for India as compared to European nations. Consider the average wage gaps for the 24 countries 
examined in Christofides et al. (2010). Only three of those European nations ${ }^{21}$ had average gender log wage gaps greater than those found in India. Among the 11 nations studied in Arulampalam et al. (2007), the largest average gender log wage gap was found in Britain (0.25) and the lowest in Italy (0.063). Our study reveals an average log wage gap of about 0.4 .

The decline in gender wage gaps as one moves from the bottom end to the top of the wage distribution is also quite drastic in the Indian case. If we look at the gender gaps due to the unexplained/discrimination component alone in the MMM results, again we find a very steep sticky floor that more than satisfies the Arulampalam et al. (2007) criteria. Thus, the sticky floor effect in India is particularly strong when compared to European nations that find a similar effect, such as Ireland, Italy and Spain.

\subsection{Possible Reasons for the Sticky Floor}

One explanation for the sticky floor might be statistical discrimination by employers. ${ }^{22}$ In India, social norms place the burden of household responsibilities disproportionately on women. Because of this, men are perceived by employers to be more reliable vis-à-vis women. Also, given the higher probability of dropping out of the labour market (for childbearing and rearing), employers discriminate against women when they enter the labour market because they expect future career interruptions. As women move up the occupation structure and gain job experience, employers become aware of their reliability and may perhaps discriminate less.

Another reason for the sticky floor could be that the nature of jobs are very different at the two ends of the distribution. Women working at the upper end are more likely to be the urban educated elite working in managerial or other professional positions. These high-wage earning women are more likely to be aware of their rights and might be in a better position to take action against perceived discrimination. According to

\footnotetext{
${ }^{21}$ Cyprus, Estonia and the Czech Republic.

${ }^{22}$ For Spain, de la Rica et al. (2008) explained the sticky floor effect for workers with low education using a similar argument.
} 
Arulampalam et al. (2007), "only the more articulate and better educated are willing to take legal action against breaches of the law" (p. 176). Employers would be aware of these possibilities themselves and hence, may not be able to discriminate a great deal between similarly qualified men and women at the upper end of the wage distribution. Moreover, the payment mechanism in jobs at the higher end would be far more structured and rigidly defined. Whether in the public sector or the private sector, most high paying jobs will have written contracts with predefined clauses for basic increases in salaries, year on year, thus making it harder to discriminate across genders.

Contrast this to a situation where an employer is paying a regular wage to a woman with no education working in an elementary occupation, a typical example of a worker at the bottom of the wage distribution in the Indian context. It is easier for the employer to discriminate in this case, as these jobs might be outside the jurisdiction of labour laws. Article 39 of the Indian constitution envisaged equal pay for equal work for both men and women. To this end legislations such as the Equal Remunerations Act (1976) were enacted. To the extent minimum wage laws are not strictly adhered to, there would be larger gender wage gaps at the bottom of the distribution. Women at the bottom may also have less bargaining power compared to men due to family commitments or social custom and are more likely to be subject to the firms' market power.

Job segregation is also a known contributor to wider gaps at the bottom as men and women only enter into exclusively 'male' and 'female' jobs. Low skilled jobs for women may pay less than other jobs that require intense physical labour, which are predominantly male jobs. Our model specifications control for broad industry and occupation groups; however, within certain low paying broad industrial categories men and women could be doing different kinds of jobs and that could be picked up as the discrimination component.

\subsection{Is This a Demand-side Story?}


One issue about working with macro data on employment and wages is that it represents the reduced form, which is an interaction of demand and supply, and we are not able to ascertain to what extent the patterns we observe are driven by demand. It is difficult to observe demand empirically; we examine the annual decadal rate of growth of Indian states as a proxy for economic activity and thus, for demand for labour, in particular for RWS work. We calculated the compound annual growth rates (CAGR) of net State Domestic Product (SDP) for all states for the period under consideration. ${ }^{23}$ Table 9 in the Appendix shows the distribution of RWS workers across Indian states along with their rates of growth of net SDP. A broad division of states into "high" and "low" growth rates states reveals a complicated picture. In the top half of high growth states, we see a few that have large shares of RWS workers - Maharashtra, Andhra Pradesh, Tamil Nadu, Gujarat, Kerala and Delhi. However, we see that some of the low growth states also have large shares (although not the largest) of RWS workers - Uttar Pradesh, West Bengal, Karnataka, Rajasthan, Madhya Pradesh and Punjab. Thus, it is not the case that all or even most states with large shares of RWS workers are high growth states.

Coming to gender gaps in shares of RWS workers, the picture is clearer. We see that among the high growth states, Delhi and Maharashtra have the largest gaps in 2009-2010; among the low growth states, Uttar Pradesh (the largest gap among all states) and Rajasthan have the largest gaps. On the whole, the average gender gap for low growth states is positive (i.e. their share among men is larger than their share among female RWS workers), whereas it is negative for high growth states. This indicates a possible positive association between high levels of economic activity and lower gender gaps in shares of RWS workers.

What about gender wage gaps? From Table 10 in the Appendix, we see that Chhattisgarh, Assam and Jharkhand have the highest gender wage gaps among all states. On average, gender wage gaps for RWS workers in 2009-2010 are smaller for the high-growth states, compared to the low-growth states, thus indicating a negative association between economic activity and gender wage gaps. Notice that the southern states, which had greater shares of female RWS workers, have positive and significant gender wage gaps.

\footnotetext{
${ }^{23}$ This was done using data on the Net State Domestic Product from the Central Statistical Organisation (CSO). We linked the constant price series to a common base of 1999-2000, as the original data presented smaller time series with changing base years.
} 
These are rough associations; the point we wish to highlight is that the links between economic activity and participation of men and women in RWS jobs and gender gaps are complicated. While growth might be necessary, it might not be sufficient in closing the gender wage gaps.

\section{Concluding Comments}

Using data from two rounds of the EUS of NSS for 1999-2000 and 2009-2010, we focus on gender differences among workers in Regular Wage/Salaried jobs. This category is heterogeneous, and includes jobs that are permanent, well paid with benefits, and are in the formal sector. Several of these workers are unionized and work in jobs that are likely to be governed by labour laws, which include anti-discrimination provisions. Thus, in several aspects, this section of workers is likely to have better outcomes than those in casual work or those at the lower-end of self-employment.

Persistently low and stagnating/declining female LFPRs in India have been discussed widely in the literature. These are a matter of concern from the larger point of view of empowerment of women. Within the existing LFPRs, we find that involvement of women in RWS work has increased over the decade, but remains low, in that of all women in the labour force, only $13 \%$ are in RWS jobs in 2009-2010 compared to $19 \%$ for men. Over the decade, educational qualifications of women in RWS jobs have increased such that in 20092010, greater proportions of RWS women have higher education than men. However, we find that the average wage gap has not declined significantly over the decade.

The wage gap continues to be positive, in that average male wages are higher than female. We find that an overwhelming part of the wage gap cannot be explained by characteristics, or is possibly discriminatory. Also, the discriminatory part of the average wage gap has increased over the decade. In particular, given the improvement in female wage earning characteristics over the decade, if women were “paid like men", women would have earned a higher average wage than men. Labour market discrimination is likely to be the main reason their wages continue to be lower than average male wages. 
Going beyond averages, decomposing the wage gaps along the entire wage distribution, we find that gaps are higher at the lower end of the distribution than the upper end, i.e. women in India face a "sticky floor", not a glass ceiling. We find that not only are the gaps higher at the lower end, the discriminatory part of the gap is also higher for workers at the lower end of the wage distribution. Over the decade, the gap has declined in the lower middle of the wage distribution.

This picture presents multi-faceted and mammoth policy challenges. It is clear that increasing female labour force participation, increasing women's share in regular wage jobs, and lowering labour market discrimination such that women earn wages commensurate with their qualifications constitute three equally urgent and important policy objectives. Given the evidence from across the globe between women's participation in economic work and higher economic growth, purely from an instrumental point of view, Indian economy would benefit immensely if these three objectives are followed seriously. Going beyond the instrumental view of women's work, the potential benefits of these objectives are immense as these are essential ingredients to achieving women's empowerment and gender equality.

\section{References}

Agrawal, Tushar (2013). Are There Glass-Ceiling and Sticky-Floor Effects in India? An Empirical Examination. Oxford Development Studies, 41:3, 322-342, DOI:10.1080/13600818.2013.804499

Albrecht, J., Björklund, A. \& Vroman, S. (2003). Is There a Glass Ceiling in Sweden? Journal of Labor Economics, 21: 145-178

Arulampalam, W., Booth, A., \& Bryan, M. (2007). Is There a Glass Ceiling over Europe? Exploring the Gender Pay Gap across the Wage Distribution. Industrial and Labor Relations Review, ILR Review, 60(2): 163-186 
Banerjee, B. \& Knight, J. B. (1985). Caste discrimination in the Indian Urban Labour Market, Journal of Development Economics, 17: 277-307.

Bhaumik, S. K. \& Chakrabarty,M. (2009) . Is Education the panacea for Economic Deprivation of Muslims?: Evidence from wage earners in India, 1987-2005. Journal of Asian Economics, 20(2): 137-149.

Blinder, A. (1973). Wage Discrimination: Reduced Form and Structural Estimates. Journal of Human Resources, 8:436-455.

Boserup, E. (1970). Women's Role in Economic Development, St. Martins, New York.

Central Statistical Organisation: The Handbook of Statistics on the Indian Economy https://rbi.org.in/Scripts/AnnualPublications.aspx?head=Handbook\%20of\%20Statistics\%20on\%20Indian\%2 0Economy (accessed 10 ${ }^{\text {th }}$ May, 2015)

Chaudhary, R. \& Verick,S. (2014). Female Labour Force Participation in India and Beyond, ILO Asia-Pacific Working Paper (New Delhi: ILO).

Chi, W. \& Bo, L. (2008). Glass Ceiling or Sticky Floor? Examining the Gender Pay Gap across the Wage Distribution in Urban China, 1987-2004.,Journal of Comparative Economics, 36: 243-263.

Christofides, L. N., Polycarpou, A. \& Vrachimis, K. (2010). The Gender Wage Gaps, 'Sticky Floors' and 'Glass Ceilings' of the European Union,. IZA Discussion Papers 5044, Institute for the Study of Labor (IZA)

De la Rica, S., Dolado, J. J. \& Llorens,V. (2008). Ceiling or Floors? Gender Wage Gaps by Education in Spain, Journal of Population Economics, Vol. 21, No. 3, pp. 751-776. 
Deshpande, A. (2007). Overlapping identities under liberalisation: gender and caste in India, Economic Development and Cultural Change, Vol. 55, No. 4, July 2007, pp.735-760

Deshpande, A. (2011). The Grammar of Caste: Economic Discrimination in Contemporary India, Oxford University Press, New Delhi.

Deshpande, A. \& Ramachandran,R. (2014). How Backward are the Other Backward Classes? Changing Contours of Caste Disadvantage in India, Centre for Development Economics, Working Paper No. 233, November 2014.

Deshpande, A. \& Sharma, S. (2016). Is Self-Employment the Answer to Caste Discrimination? Decomposing the Earnings Gap in Indian Household Non-farm Business, Small Business Economics: An Entrepreneurship Journal, 46(2):325-346

Deshpande, S. \& Deshpande, L. K. (1997). Gender Based Discrimination in the Urban Labour Market in India, Indian Journal of Labour Economics, 40(3): 545-562.

Duraisamy, M. \& Duraisamy, P. (1999). Gender Bias in Scientific and Technical Labour Market: A Comparative Study of Tamil Nadu and Kerala, Indian Economic Review, New Series, 34(2): 149-169.

Duraisamy, P. \& Duraisamy,M. (2005). Regional Differences in Wage Premia and Returns to Education by Gender in India, Indian Journal of Labour Economics, 48(2): 335-347.

Fang, Z. \& Sakellariou,C. (2011). A Case of Sticky Floors: Gender Wage Differentials in Thailand, Asian Economic Journal, 25: 35-54. doi: 10.1111/j.1467-8381.2011.02047.x 
Firpo, S., Fortin, N. \& Lemieux, M. (2009) . Unconditional Quantile Regressions. Econometrica, 77: 953973. doi: 10.3982/ECTA6822

Gunewardena, D, Abeyrathna, D., Ellagala, A., Rajakaruna, K. \& Rajendran,S. (2008). Glass Ceilings, Sticky Floors or Sticky Doors? A Quantile Regression Approach to Exploring Gender Wage Gaps in Sri Lanka, PMMA Working Paper No. 2008-04. Available at SSRN: http://ssrn.com/abstract=1124158 or http://dx.doi.org/10.2139/ssrn.1124158

Hnatkovska, V., Lahiri, A. \& Paul, S. (2012). Castes and Labor Mobility. American Economic Journal: Applied Economics, 4(2): 274-307

Jose, A. V. (1988). Agricultural Wages in India, Economic and Political Weekly, 23(26), June 25, pp. A-46 to A-58.

Khanna, S., (2012). Gender Wage Discrimination in India: Glass Ceiling or Sticky Floor?, Centre for Development Economics Working Paper, No. 214.

Kingdon, G. G. \& Unni, J. (2001). Education and Women's Labour Market Outcomes in India, Education Economics, 9(2): 173-195.

Klasen, S. \& Pieters, J. (2012). Push or Pull? Drivers of Female Labour Force Participation during India's Economic Boom, IZA Discussion Paper No. 6395.

Klasen, S. \& Pieters, J. (2015). What Explains the Stagnation of Female Labour Force Participation in Urban India?, forthcoming World Bank Economic Review. doi: 10.1093/wber/lhv003.

Koenker, R. \& Bassett, G. (1978). Regression Quantiles. Econometrica, 46, 33- 50. 
Machado, J.A. \& Mata, J. (2005) Counterfactual decomposition of changes in wage distributions using quantile regression. Journal of Applied Econometrics, John Wiley \& Sons, Ltd., vol. 20(4), pages 445-465

Madheswaran, S. \& Attewell, P. (2007). Caste Discrimination in the Indian Urban Labor Market: Evidence from the National Sample Survey of India, Economic and Political Weekly, October 132007 pp. 4146-4153

Madheswaran, S. \& Khasnobis, B. G. (2007). Gender Discrimination in the Labour Market: Evidence from the NSS. WIDER research project on "Gender wage Gap and its Impact on Poverty: Evidence from India"

Mahajan, K. \& Ramaswami, B. (2015). Caste, Female Labour Supply and the Gender Wage Gap in India: Boserup Revisited, Indian Statistical Institute, Working Paper

Melly, B. (2006), Estimation of counterfactual distributions using quantile regression. University of St. Gallen, Discussion Paper

Mukherjee, D. \& Majumder, R. (2011). Occupational Pattern, Wage Rates and Earnings Disparities in India. Indian Economic Review, 46(1): 131-152.

Mukhopadhyay, S. \& Tendulkar, S. D. (2006). Gender Differences in Labour Force Participation in India: An analysis of NSS data, Institute of Social Studies Trust Working Paper, GN(III)/2006/WP2

Oaxaca, R. L., (1973). Male-Female Wage Differentials in Urban Labour Markets, International Economic Review, 14: 693-709.

Pham, T. \& Reilly,B. (2007). The Gender Pay Gap In Vietnam, 1993-2002: A Quantile Regression Approach, Journal of Asian Economics, 18(5): 775-808. 
Sakellariou, C. (2004). The use of quantile regressions in estimating gender wage differentials: a case study of the Philippines. Applied Economics, 36(9): 1001-1007.

Seguino, Stephanie (2000). Gender Inequality and Economic Growth: A cross-country analysis. World Development, 28 (7): 1211-1230

Varkkey, B. \& R. Korde. (2013). Gender Pay Gap in the Formal Sector: 2006-2013, Preliminary Evidences from Paycheck India Data, WageIndiacator Data Report, Report Series 003. 


\section{TABLES AND FIGURES}

Fig.1 Gender Wage Gaps across Percentiles and at the Mean (with Confidence Intervals, CI), 1999-2000 and 2009-2010

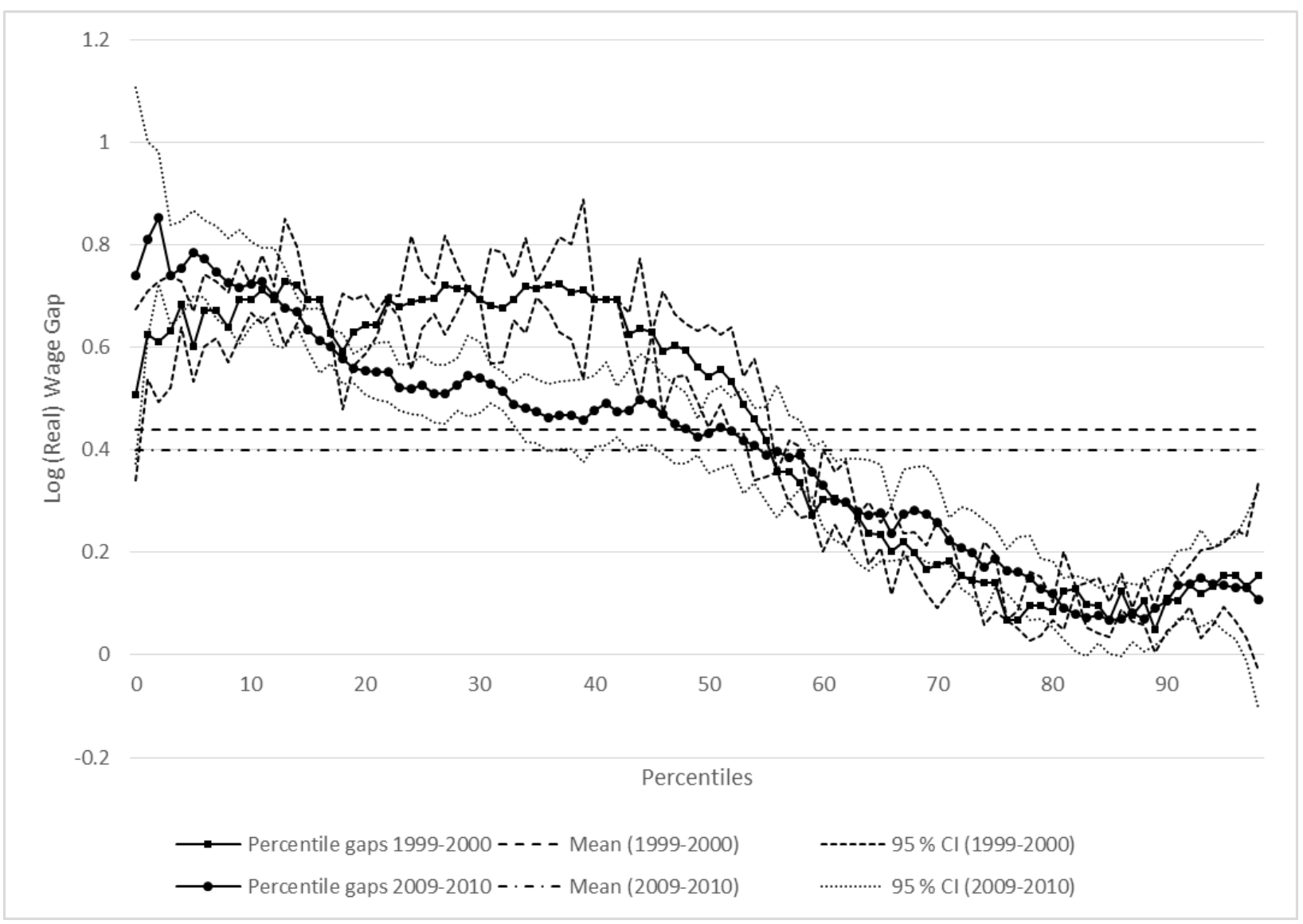


Fig. 2 MMM Decomposition using Male Wage Structure, 1999- 2000

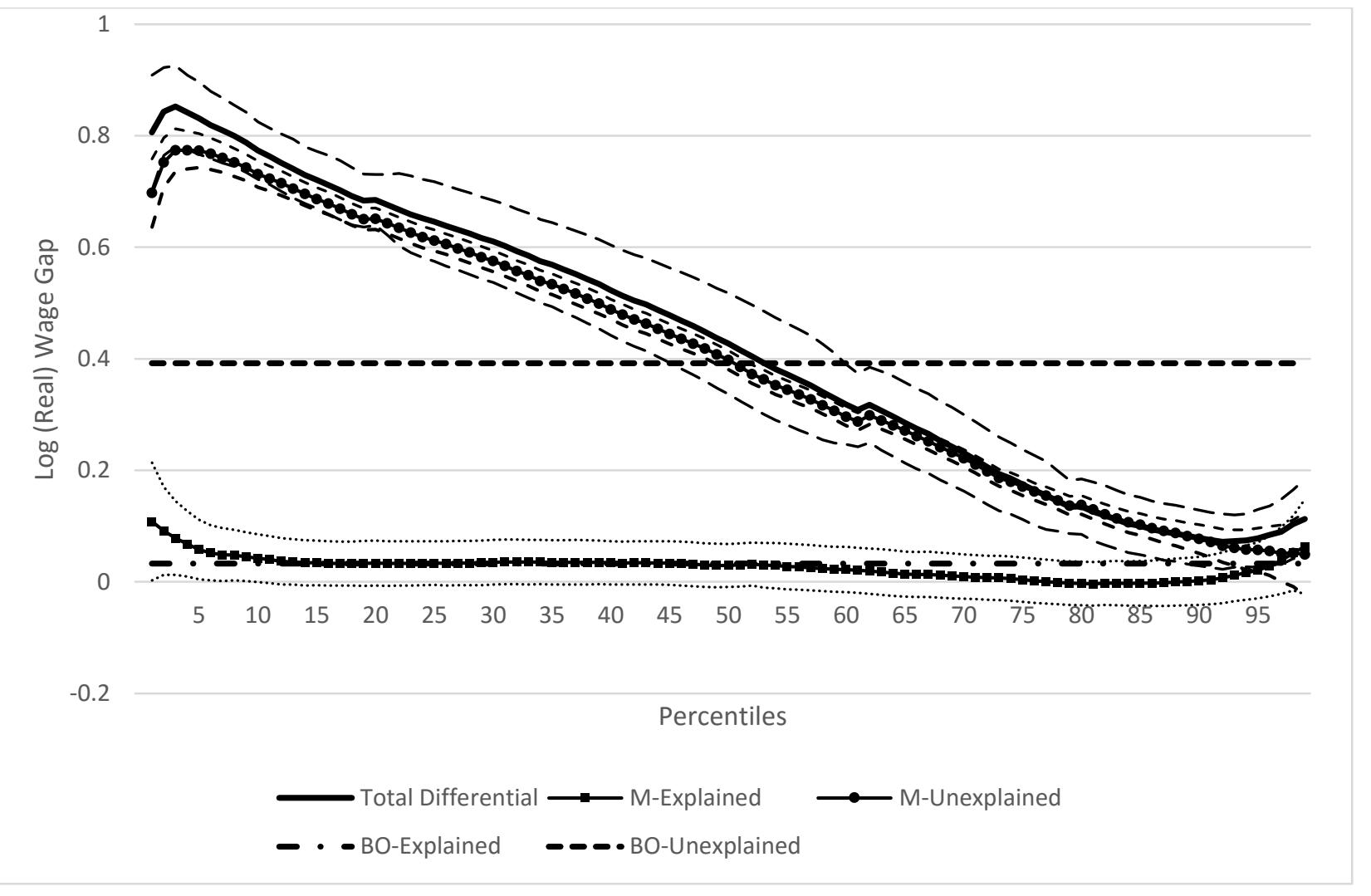

Fig. 3: MMM Decomposition using Male Wage Structure, 2009-2010

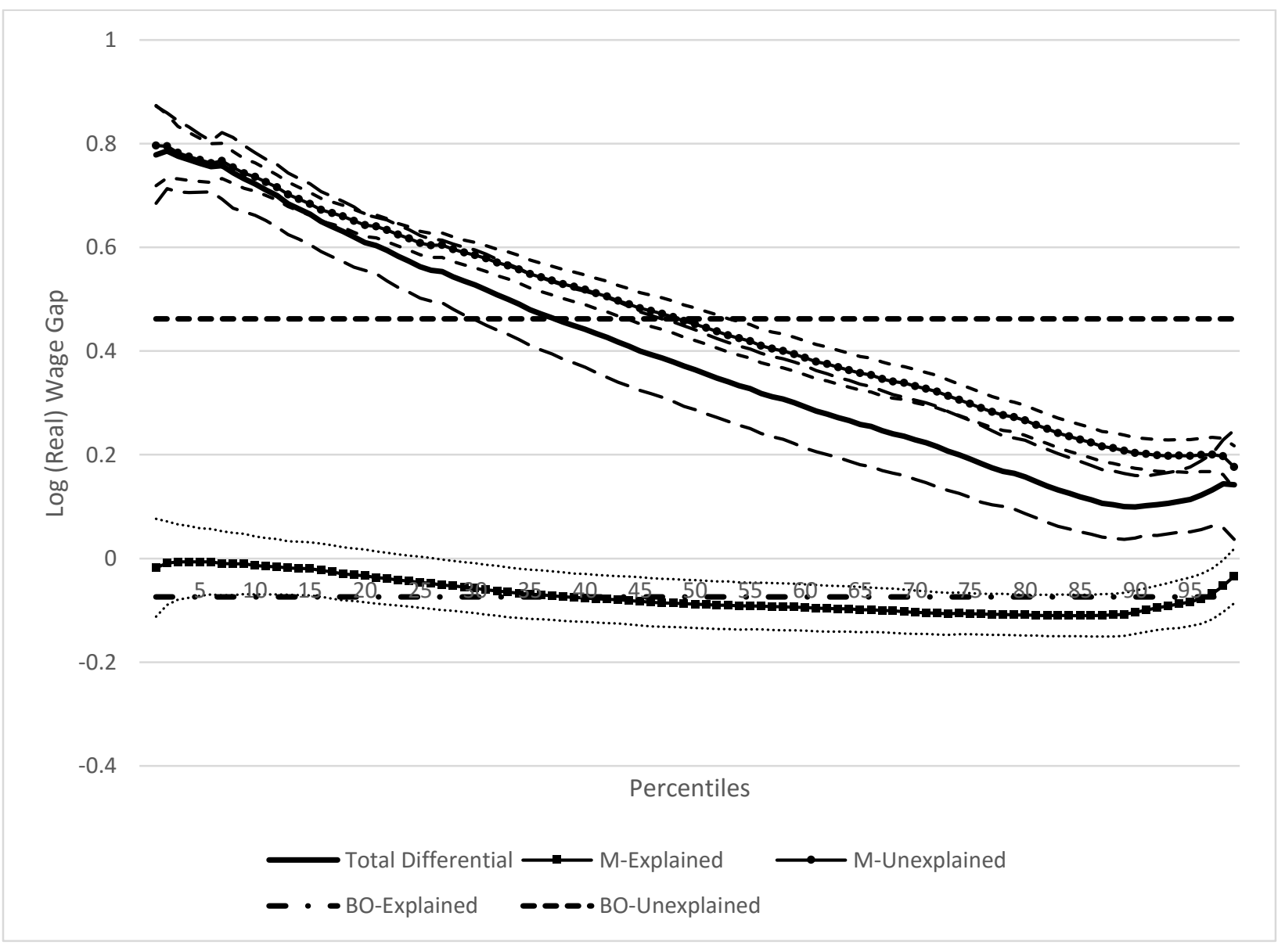




\begin{tabular}{|l|c|c|c|c|c|c|}
\hline \multicolumn{3}{|c|}{ Table 1: Categorising the Labour Force (\% of Labour Force) } \\
& \multicolumn{3}{|c|}{$1999-2000$} & \multicolumn{3}{c|}{$2009-2010$} \\
\cline { 2 - 7 } & Males & Females & All Persons & Males & Females & All Persons \\
\hline Casual Labour & 31.5 & 42.3 & 34.4 & 32.5 & 38.8 & 34.0 \\
\hline Regular Wage Salaried & 18.1 & 9.3 & 15.7 & 18.7 & 12.7 & 17.3 \\
\hline Self Employed & 47.4 & 45.9 & 47.0 & 46.5 & 44.9 & 46.1 \\
\hline Unemployed & 3.1 & 2.5 & 2.9 & 2.4 & 3.5 & 2.6 \\
\hline Total & 100 & 100 & 100 & 100 & 100 & 100 \\
\hline
\end{tabular}


Table 2: Education Shares and Wages by Gender

\begin{tabular}{|c|c|c|c|c|c|c|}
\hline & \multicolumn{3}{|c|}{$1999-2000$} & \multicolumn{3}{|c|}{$2009-2010$} \\
\hline & Male & Female & All Persons & Male & Female & All Persons \\
\hline \multicolumn{7}{|c|}{ Educational Distribution of RWS Workers (in \%) } \\
\hline Illiterates & 9.4 & 22.5 & 11.5 & 6.1 & 14.9 & 7.6 \\
\hline Primary and Below & 17.3 & 13.7 & 16.7 & 14.0 & 12.0 & 13.6 \\
\hline Middle & 17.5 & 9.6 & 16.3 & 16.2 & 10.6 & 15.2 \\
\hline Secondary, Higher Sec. & 33.1 & 28.0 & 32.3 & 30.0 & 19.9 & 28.2 \\
\hline Graduate and Above & 22.7 & 26.3 & 23.3 & 33.8 & 42.6 & 35.3 \\
\hline Total & 100 & 100 & 100 & 100 & 100 & 100 \\
\hline \multicolumn{7}{|c|}{ Average Wages (in 1999-2000 Rupees per Day) } \\
\hline Illiterates & 80.8 & 47.1 & 70.6 & 83.8 & 49.1 & 72.0 \\
\hline Primary and Below & 92.1 & 59.8 & 88.0 & 89.8 & 56.5 & 84.7 \\
\hline Middle & 106.7 & 65.2 & 102.9 & 108.4 & 64.2 & 103.0 \\
\hline Secondary, Higher Sec. & 160.3 & 140.4 & 157.7 & 163.0 & 116.6 & 157.3 \\
\hline Graduate and Above & 266.7 & 212.9 & 257.2 & 305.2 & 248.3 & 293.3 \\
\hline Overall & 155.8 & 120.3 & 150.3 & 187.2 & 149.9 & 180.7 \\
\hline \multicolumn{7}{|c|}{ Gender Log Wage Gap (in \% at the mean) } \\
\hline & \multicolumn{3}{|c|}{$1999-2000$} & \multicolumn{3}{|c|}{$2009-2010$} \\
\hline Illiterates & \multicolumn{3}{|c|}{$76.4^{* * *}$} & \multicolumn{3}{|c|}{$94.0^{* * *}$} \\
\hline Primary and Below & \multicolumn{3}{|c|}{$62.0^{* * *}$} & \multicolumn{3}{|c|}{$67.9^{* * *}$} \\
\hline Middle & \multicolumn{3}{|c|}{$84.2 * * *$} & \multicolumn{3}{|c|}{$76.8 * * *$} \\
\hline Secondary, Higher Sec. & \multicolumn{3}{|c|}{$38.4^{* * *}$} & \multicolumn{3}{|c|}{$63.4^{* * *}$} \\
\hline Graduate and Above & \multicolumn{3}{|c|}{$33.5^{* * *}$} & \multicolumn{3}{|c|}{$30.6^{* * *}$} \\
\hline Overall & \multicolumn{3}{|c|}{$55.1^{* * *}$} & \multicolumn{3}{|c|}{$49.1^{* * *}$} \\
\hline \multicolumn{7}{|c|}{$1.1 \dagger$ indicates significance at $10 \%, *$ at $5 \%, * *$ at $1 \%$ and $* * *$ at $0.1 \%$} \\
\hline
\end{tabular}


Table 3: Shares and Wages across Employment Types by Gender

\begin{tabular}{|c|c|c|c|c|c|c|}
\hline \multicolumn{7}{|c|}{ Public/Private } \\
\hline & \multicolumn{3}{|c|}{$1999-2000$} & \multicolumn{3}{|c|}{$2009-2010$} \\
\hline & Male & Female & All Persons & Male & Female & All Persons \\
\hline \multicolumn{7}{|c|}{ Public/Private Distribution of RWS Workers } \\
\hline Public Sector & 36.2 & 39.1 & 36.7 & 32.1 & 39.8 & 33.5 \\
\hline Private Sector & 63.8 & 60.9 & 63.3 & 67.9 & 60.2 & 66.5 \\
\hline Total & 100 & 100 & 100 & 100 & 100 & 100 \\
\hline \multicolumn{7}{|c|}{ Average Wages (in 1999-2000 Rupees per Day) } \\
\hline Public Sector & 229.9 & 186.9 & 222.9 & 291.7 & 215.2 & 275.9 \\
\hline Private Sector & 120.4 & 86.2 & 115.4 & 141.4 & 111.1 & 136.7 \\
\hline \multicolumn{7}{|c|}{ Gender Log Wage Gap (in \% at the mean) } \\
\hline & \multicolumn{3}{|c|}{$1999-2000$} & \multicolumn{3}{|c|}{$2009-2010$} \\
\hline Public Sector & \multicolumn{3}{|c|}{$42.8^{* * *}$} & \multicolumn{3}{|c|}{$68.5^{* * *}$} \\
\hline Private Sector & \multicolumn{3}{|c|}{$68.2^{* * *}$} & \multicolumn{3}{|c|}{$52.2^{* * *}$} \\
\hline \multicolumn{7}{|c|}{ Union/Non-Union } \\
\hline & \multicolumn{3}{|c|}{$1999-2000$} & \multicolumn{3}{|c|}{$2009-2010$} \\
\hline & Male & Female & All Persons & Male & Female & All Persons \\
\hline \multicolumn{7}{|c|}{ Union Distribution of Regular Salaried Workers } \\
\hline Non-Union Member & 54.1 & 54.2 & 54.1 & 66.6 & 67.2 & 66.7 \\
\hline Union Member & 45.9 & 45.8 & 45.9 & 33.5 & 32.8 & 33.4 \\
\hline Total & 100 & 100 & 100 & 100 & 100 & 100 \\
\hline \multicolumn{7}{|c|}{ Average Wages (in 1999-2000 Rupees per Day) } \\
\hline Non-Union Member & 112.4 & 74.8 & 106.6 & 143.5 & 104.7 & 136.7 \\
\hline Union Member & 207.9 & 175.5 & 202.9 & 275.4 & 245.8 & 270.4 \\
\hline \multicolumn{7}{|c|}{ Gender Log Wage Gap (in \% at the mean) } \\
\hline & \multicolumn{3}{|c|}{$1999-2000$} & \multicolumn{3}{|c|}{$2009-2010$} \\
\hline Non-Union Member & \multicolumn{3}{|c|}{$68.8^{* * *}$} & \multicolumn{3}{|c|}{$61.5^{* * *}$} \\
\hline Union Member & \multicolumn{3}{|c|}{$39.1^{* * *}$} & \multicolumn{3}{|c|}{$23.4^{* * *}$} \\
\hline \multicolumn{7}{|c|}{ Temporary/Permanent } \\
\hline
\end{tabular}




\begin{tabular}{|c|c|c|c|c|c|c|}
\hline & \multicolumn{3}{|c|}{$1999-2000$} & \multicolumn{3}{|c|}{$2009-2010$} \\
\hline & Male & Female & All Persons & Male & Female & All Persons \\
\hline \multicolumn{7}{|c|}{ Permanent/Temporary Distribution of Regular Salaried Workers } \\
\hline Temporary & 27.3 & 28.7 & 27.5 & 31.8 & 31.1 & 31.7 \\
\hline Permanent & 72.8 & 71.3 & 72.5 & 68.2 & 68.9 & 68.3 \\
\hline Total & 100 & 100 & 100 & 100 & 100 & 100 \\
\hline \multicolumn{7}{|c|}{ Average Wages (in 1999-2000 Rupees per Day) } \\
\hline Temporary & 79.1 & 50.9 & 74.6 & 98.32 & 71.97 & 93.84 \\
\hline Permanent & 184.7 & 148.8 & 179.2 & 228.72 & 185.58 & 221.16 \\
\hline \multicolumn{7}{|c|}{ Gender Log Wage Gap (in \% at the mean) } \\
\hline & \multicolumn{3}{|c|}{ 1999-2000 } & \multicolumn{3}{|c|}{ 2009-2010 } \\
\hline Temporary & \multicolumn{3}{|c|}{$70.9^{* * *}$} & \multicolumn{3}{|c|}{$54.7^{* * *}$} \\
\hline Permanent & \multicolumn{3}{|c|}{$46.3^{* * *}$} & \multicolumn{3}{|c|}{$47.6^{* * *}$} \\
\hline \multicolumn{7}{|c|}{$1.2+$ indicates significance at $10 \%, *$ at $5 \%, * *$ at $1 \%$ and $* * *$ at $0.1 \%$} \\
\hline
\end{tabular}




\begin{tabular}{|c|c|c|c|c|c|c|}
\hline \multicolumn{7}{|c|}{ Table 4: Caste Shares and Wages by Gender } \\
\hline & \multicolumn{3}{|c|}{ 1999-2000 } & \multicolumn{3}{|c|}{ 2009-2010 } \\
\hline & Male & Female & All Persons & Male & Female & All Persons \\
\hline \multicolumn{7}{|c|}{ Caste Distribution of RWS Workers (in \%) } \\
\hline Scheduled Tribe & 5.2 & 7.2 & 5.5 & 4.8 & 5.0 & 4.8 \\
\hline Scheduled Caste & 14.8 & 15.4 & 14.9 & 16.3 & 19.4 & 16.9 \\
\hline Other Backward Classes & 29.4 & 29.5 & 29.4 & 35.7 & 34.9 & 35.5 \\
\hline Upper Caste & 50.7 & 47.8 & 50.3 & 43.2 & 40.7 & 42.8 \\
\hline Total & 100 & 100 & 100 & 100 & 100 & 100 \\
\hline \multicolumn{7}{|c|}{ Average Wages (in 1999-2000 Rupees per Day) } \\
\hline Scheduled Tribe & 155.5 & 112.9 & 146.7 & 172.5 & 128.3 & 164.4 \\
\hline Scheduled Caste & 131.7 & 89.9 & 125.0 & 151.0 & 90.6 & 138.9 \\
\hline Other Backward Classes & 128.8 & 87.3 & 122.3 & 166.7 & 124.8 & 159.6 \\
\hline Upper Caste & 178.4 & 151.5 & 174.4 & 219.4 & 202.3 & 216.6 \\
\hline \multicolumn{7}{|c|}{ Gender Log Wage Gap (in \% at the mean) } \\
\hline & \multicolumn{3}{|c|}{ 1999-2000 } & \multicolumn{3}{|c|}{$2009-2010$} \\
\hline Scheduled Tribe & \multicolumn{3}{|c|}{$54.4^{* * *}$} & \multicolumn{3}{|c|}{$61.8^{* * *}$} \\
\hline Scheduled Caste & \multicolumn{3}{|c|}{$65.5^{* * *}$} & \multicolumn{3}{|c|}{$86.5^{* * *}$} \\
\hline Other Backward Classes & \multicolumn{3}{|c|}{$78.5^{* * *}$} & \multicolumn{3}{|c|}{$50.7^{* * *}$} \\
\hline Upper Caste & \multicolumn{3}{|c|}{$38.0^{* * *}$} & \multicolumn{3}{|c|}{$28.1^{* * *}$} \\
\hline \multicolumn{7}{|c|}{$1.3+$ indicates significance at $10 \%, *$ at $5 \%, * *$ at $1 \%$ and $* * *$ at $0.1 \%$} \\
\hline
\end{tabular}


Table 5: OLS Regressions, Partial and Full Specifications, 1999-2000 and 2009-2010a

\begin{tabular}{|c|c|c|c|c|c|c|c|}
\hline \multicolumn{3}{|c|}{ Partial } & \multicolumn{3}{c|}{ Full } \\
\hline 1999-2000 & \multicolumn{2}{|c|}{$2009-2010$} & \multicolumn{2}{c|}{$1999-2000$} & \multicolumn{2}{c|}{$2009-2010$} \\
\hline Coeff. & t-ratio & Coeff. & t-ratio & Coeff. & t-ratio & Coeff. & t-ratio \\
\hline
\end{tabular}

Pooled (Men and Women) Sample

\begin{tabular}{|c|c|c|c|c|c|c|c|c|}
\hline Male & 0.33 & 17.02 & 0.38 & 17.07 & 0.37 & 19.20 & 0.43 & 18.51 \\
\hline Age & 0.06 & 14.36 & 0.03 & 5.76 & 0.04 & 9.03 & 0.02 & 4.65 \\
\hline Age Squared & -0.04 & -7.87 & -0.01 & -0.87 & -0.03 & -5.44 & -0.01 & -2.09 \\
\hline Married & 0.16 & 8.55 & 0.13 & 5.72 & 0.07 & 3.97 & 0.08 & 3.74 \\
\hline Urban & 0.17 & 10.93 & 0.21 & 10.45 & 0.18 & 11.56 & 0.25 & 13.59 \\
\hline ST & 0.11 & 3.59 & -0.02 & -0.63 & 0.02 & 0.52 & -0.08 & -2.53 \\
\hline SC & -0.01 & -0.39 & -0.10 & -4.62 & -0.08 & -4.02 & -0.14 & -7.01 \\
\hline OBC & -0.07 & -5.23 & -0.11 & -5.61 & -0.08 & -6.50 & -0.11 & -5.89 \\
\hline Primary and Below & 0.22 & 9.75 & 0.20 & 6.67 & 0.10 & 4.22 & 0.10 & 3.28 \\
\hline Middle & 0.38 & 18.02 & 0.36 & 12.05 & 0.20 & 8.98 & 0.20 & 7.04 \\
\hline Secondary, Higher Sec. & 0.72 & 35.95 & 0.67 & 23.74 & 0.39 & 16.80 & 0.37 & 12.87 \\
\hline Graduate and Above & 1.15 & 47.61 & 1.30 & 42.12 & 0.68 & 24.54 & 0.73 & 17.61 \\
\hline Public & No & & No & & 0.25 & 14.20 & 0.31 & 13.35 \\
\hline Union Member & No & & No & & 0.28 & 15.64 & 0.23 & 13.70 \\
\hline Permanent & No & & No & & 0.26 & 16.70 & 0.25 & 15.23 \\
\hline Regions & Yes & & Yes & & Yes & & Yes & \\
\hline Occupation & No & & No & & Yes & & Yes & \\
\hline Industry & No & & No & & Yes & & Yes & \\
\hline R Squared & 0.48 & & 0.46 & & 0.59 & & 0.56 & \\
\hline Observations & 34102 & & 33658 & & 28538 & & 31274 & \\
\hline \multicolumn{9}{|c|}{ Male Sample } \\
\hline Age & 0.06 & 13.59 & 0.03 & 6.09 & 0.04 & 8.43 & 0.03 & 5.30 \\
\hline Age Squared & -0.05 & -8.10 & -0.01 & -1.59 & -0.03 & -5.52 & -0.02 & -2.95 \\
\hline Married & 0.16 & 7.10 & 0.12 & 4.48 & 0.09 & 4.21 & 0.08 & 3.09 \\
\hline Urban & 0.16 & 9.77 & 0.18 & 8.39 & 0.15 & 9.55 & 0.21 & 10.78 \\
\hline
\end{tabular}




\begin{tabular}{|c|c|c|c|c|c|c|c|c|}
\hline \multicolumn{9}{|c|}{ Table 5: OLS Regressions, Partial and } \\
\hline+2 & \multicolumn{4}{|c|}{$\begin{array}{l}\text { Partial } \\
\end{array}$} & \multicolumn{4}{|c|}{ Full } \\
\hline & \multicolumn{2}{|c|}{$1999-2000$} & \multicolumn{2}{|c|}{ 2009-2010 } & \multicolumn{2}{|c|}{$1999-2000$} & \multicolumn{2}{|c|}{$2009-2010$} \\
\hline & Coeff. & t-ratio & Coeff. & t-ratio & Coeff. & t-ratio & Coeff. & t-ratio \\
\hline ST & 0.09 & 2.88 & -0.03 & -0.75 & -0.01 & -0.38 & -0.09 & -2.66 \\
\hline SC & -0.03 & -1.42 & -0.09 & -3.87 & -0.09 & -4.36 & -0.15 & -7.23 \\
\hline OBC & -0.06 & -4.51 & -0.11 & -5.15 & -0.08 & -5.87 & -0.11 & -5.41 \\
\hline Primary and Below & 0.16 & 7.21 & 0.09 & 3.03 & 0.03 & 1.25 & 0.01 & 0.39 \\
\hline Middle & 0.32 & 14.42 & 0.25 & 8.22 & 0.14 & 5.82 & 0.12 & 4.02 \\
\hline Secondary, Higher Sec. & 0.63 & 30.10 & 0.54 & 18.76 & 0.31 & 12.92 & 0.28 & 9.34 \\
\hline Graduate and Above & 1.05 & 37.60 & 1.12 & 33.39 & 0.57 & 18.54 & 0.56 & 13.32 \\
\hline Public & No & & No & & 0.24 & 13.04 & 0.33 & 13.36 \\
\hline Union Member & No & & No & & 0.25 & 13.22 & 0.19 & 10.92 \\
\hline Permanent & No & & No & & 0.22 & 13.81 & 0.24 & 13.57 \\
\hline Regions & Yes & & Yes & & Yes & & Yes & \\
\hline Occupation & No & & No & & Yes & & Yes & \\
\hline Industry & No & & No & & Yes & & Yes & \\
\hline R Squared & 0.47 & & 0.44 & & 0.58 & & 0.55 & \\
\hline Observations & 28462 & & 27668 & & 23845 & & 25724 & \\
\hline \multicolumn{9}{|c|}{ Female Sample } \\
\hline Age & 0.05 & 4.49 & 0.03 & 2.62 & 0.02 & 1.65 & 0.02 & 1.94 \\
\hline Age Squared & -0.02 & -1.66 & -0.01 & -0.42 & 0.00 & 0.15 & -0.01 & -0.75 \\
\hline Married & 0.11 & 3.04 & 0.08 & 2.01 & 0.03 & 0.96 & 0.03 & 0.83 \\
\hline Urban & 0.21 & 5.04 & 0.33 & 8.01 & 0.26 & 6.26 & 0.37 & 9.16 \\
\hline ST & 0.23 & 2.60 & -0.03 & -0.40 & 0.17 & 2.05 & -0.09 & -1.11 \\
\hline SC & 0.10 & 2.18 & -0.11 & -1.93 & 0.01 & 0.2 & -0.11 & -2.08 \\
\hline OBC & -0.11 & -2.80 & -0.11 & -2.47 & -0.11 & -2.53 & -0.13 & -2.93 \\
\hline Primary and Below & 0.30 & 4.58 & 0.31 & 4.65 & 0.23 & 3.5 & 0.19 & 2.82 \\
\hline Middle & 0.43 & 7.33 & 0.49 & 6.70 & 0.30 & 4.26 & 0.31 & 4.49 \\
\hline Secondary, Higher Sec. & 1.00 & 20.78 & 0.96 & 14.60 & 0.76 & 9.53 & 0.67 & 7.86 \\
\hline
\end{tabular}




\begin{tabular}{|c|c|c|c|c|c|c|c|c|}
\hline Table 5 & Regres & ons, Part & and Fu & pecificat & 1999 & 00 and & $-2010^{a}$ & ntinued \\
\hline & & & & & & & & \\
\hline & $\overline{199}$ & 2000 & 200 & 2010 & 199 & 2000 & & 010 \\
\hline & Coeff. & t-ratio & Coeff. & t-ratio & Coeff. & t-ratio & Coeff. & t-ratio \\
\hline Graduate and Above & 1.45 & 34.06 & 1.71 & 30.09 & 1.11 & 13.59 & 1.33 & 11.75 \\
\hline Public & No & & No & & 0.30 & 6.59 & 0.28 & 5.68 \\
\hline Union Member & No & & No & & 0.40 & 8.94 & 0.36 & 8.56 \\
\hline Permanent & No & & No & & 0.40 & 9.33 & 0.29 & 6.97 \\
\hline Regions & Yes & & Yes & & Yes & & Yes & \\
\hline Occupation & No & & No & & Yes & & Yes & \\
\hline Industry & No & & No & & Yes & & Yes & \\
\hline R Squared & 0.46 & & 0.49 & & 0.6 & & 0.59 & \\
\hline Observations & 5640 & & 5990 & & 4693 & & 5550 & \\
\hline 1.4 & & 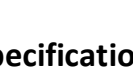 & se & d & ates & uct & s $f$ & \\
\hline
\end{tabular}


Table 6: Quantile Regressions, Full Specification, 2009-2010a

\begin{tabular}{|c|c|c|c|c|c|c|c|c|c|c|}
\hline \multicolumn{11}{|c|}{ Table 6: Quantile Regressions, Full Specification, 2009-2010a } \\
\hline & \multicolumn{2}{|c|}{$1^{\text {st }}$ Decile } & \multicolumn{2}{|c|}{$3^{\text {rd }}$ Decile } & \multicolumn{2}{|c|}{ Median } & \multicolumn{2}{|c|}{$7^{\text {th }}$ Decile } & \multicolumn{2}{|c|}{$9^{\text {th }}$ Decile } \\
\hline & Coeff. & t-ratio & Coeff. & t-ratio ${ }^{1}$ & Coeff. & t-ratio ${ }^{1}$ & Coeff. & t-ratio & Coeff. & t-ratio \\
\hline \multicolumn{11}{|c|}{ Pooled Sample (N=31274) } \\
\hline Male & 0.63 & 28.18 & 0.49 & 35.07 & 0.39 & 25.98 & 0.32 & 19.66 & 0.34 & 15.22 \\
\hline Age & 0.03 & 4.75 & 0.02 & 5.84 & 0.02 & 6.14 & 0.02 & 5.62 & 0.02 & 4.19 \\
\hline Age Squared & -0.03 & -3.74 & -0.01 & -2.67 & -0.01 & -2.49 & -0.01 & -1.75 & -0.01 & -1.33 \\
\hline Married & 0.17 & 5.88 & 0.12 & 8.84 & 0.05 & 3.59 & 0.03 & 1.89 & -0.01 & -0.39 \\
\hline Urban & 0.28 & 11.29 & 0.24 & 20.96 & 0.21 & 18.33 & 0.19 & 15.79 & 0.19 & 12.12 \\
\hline SC & -0.13 & -4.94 & -0.11 & -8.12 & -0.15 & -9.96 & -0.16 & -10.14 & -0.13 & -6.29 \\
\hline OBC & -0.11 & -4.49 & -0.08 & -6.83 & -0.10 & -7.46 & -0.10 & -7.47 & -0.12 & -6.14 \\
\hline Primary and Below & 0.12 & 3.18 & 0.07 & 3.01 & 0.10 & 3.98 & 0.09 & 3.73 & 0.07 & 2.22 \\
\hline Middle & 0.21 & 5.44 & 0.19 & 8.86 & 0.18 & 7.50 & 0.21 & 8.51 & 0.19 & 5.88 \\
\hline Secondary, Higher Sec. & 0.35 & 9.50 & 0.34 & 16.48 & 0.33 & 14.58 & 0.37 & 15.39 & 0.38 & 12.40 \\
\hline Graduate and Above & 0.58 & 10.64 & 0.66 & 27.21 & 0.67 & 26.17 & 0.73 & 26.87 & 0.79 & 22.61 \\
\hline Public & 0.30 & 10.48 & 0.37 & 25.17 & 0.40 & 26.46 & 0.33 & 20.40 & 0.24 & 9.23 \\
\hline Union Member & 0.28 & 12.30 & 0.28 & 23.82 & 0.23 & 18.67 & 0.17 & 12.82 & 0.13 & 6.36 \\
\hline
\end{tabular}


Table 6: Quantile Regressions, Full Specification, 2009-2010a

\begin{tabular}{|c|c|c|c|c|c|c|c|c|c|c|}
\hline \multicolumn{11}{|c|}{ Table 6: Quantile Regressions, Full Specification, 2009-2010a } \\
\hline & \multicolumn{2}{|c|}{$1^{\text {st }}$ Decile } & \multicolumn{2}{|c|}{$3^{\text {rd }}$ Decile } & \multicolumn{2}{|c|}{ Median } & \multicolumn{2}{|c|}{$7^{\text {th }}$ Decile } & \multicolumn{2}{|c|}{$9^{\text {th }}$ Decile } \\
\hline & Coeff. & t-ratio & Coeff. & t-ratio ${ }^{1}$ & Coeff. & t-ratio ${ }^{1}$ & Coeff. & t-ratio & Coeff. & t-ratio \\
\hline Regions & Yes & & Yes & & Yes & & Yes & & Yes & \\
\hline Occupation & Yes & & Yes & & Yes & & Yes & & Yes & \\
\hline Industry & Yes & & Yes & & Yes & & Yes & & Yes & \\
\hline \multicolumn{11}{|c|}{ Male Sample ( $=25724)$} \\
\hline Age & 0.04 & 6.35 & 0.03 & 5.60 & 0.03 & 6.53 & 0.02 & 6.39 & 0.02 & 3.81 \\
\hline Age Squared & -0.05 & -5.53 & -0.02 & -3.21 & -0.02 & -3.41 & -0.01 & -2.30 & -0.01 & -1.22 \\
\hline Urban & 0.24 & 9.64 & 0.18 & 12.94 & 0.18 & 13.89 & 0.17 & 15.30 & 0.17 & 9.96 \\
\hline ST & -0.09 & -2.03 & -0.09 & -3.16 & -0.10 & -3.66 & -0.10 & -3.90 & -0.16 & -5.28 \\
\hline SC & -0.13 & -5.22 & -0.14 & -8.32 & -0.15 & -8.85 & -0.16 & -10.66 & -0.15 & -6.44 \\
\hline OBC & -0.10 & -4.38 & -0.10 & -6.70 & -0.09 & -6.59 & -0.10 & -7.16 & -0.10 & -5.00 \\
\hline Primary and Below & 0.05 & 1.24 & 0.00 & 0.17 & 0.03 & 1.06 & 0.00 & 0.06 & 0.02 & 0.60 \\
\hline Middle & 0.14 & 3.95 & 0.12 & 4.38 & 0.11 & 3.83 & 0.12 & 5.08 & 0.14 & 3.75 \\
\hline Secondary, Higher Sec. & 0.27 & 7.48 & 0.26 & 10.08 & 0.27 & 10.01 & 0.29 & 12.18 & 0.32 & 9.22 \\
\hline Graduate and Above & 0.42 & 7.68 & 0.51 & 16.51 & 0.56 & 18.44 & 0.59 & 22.54 & 0.68 & 18.12 \\
\hline Union Member & 0.27 & 12.42 & 0.24 & 16.36 & 0.19 & 13.90 & 0.14 & 10.64 & 0.12 & 5.71 \\
\hline
\end{tabular}


Table 6: Quantile Regressions, Full Specification, 2009-2010a

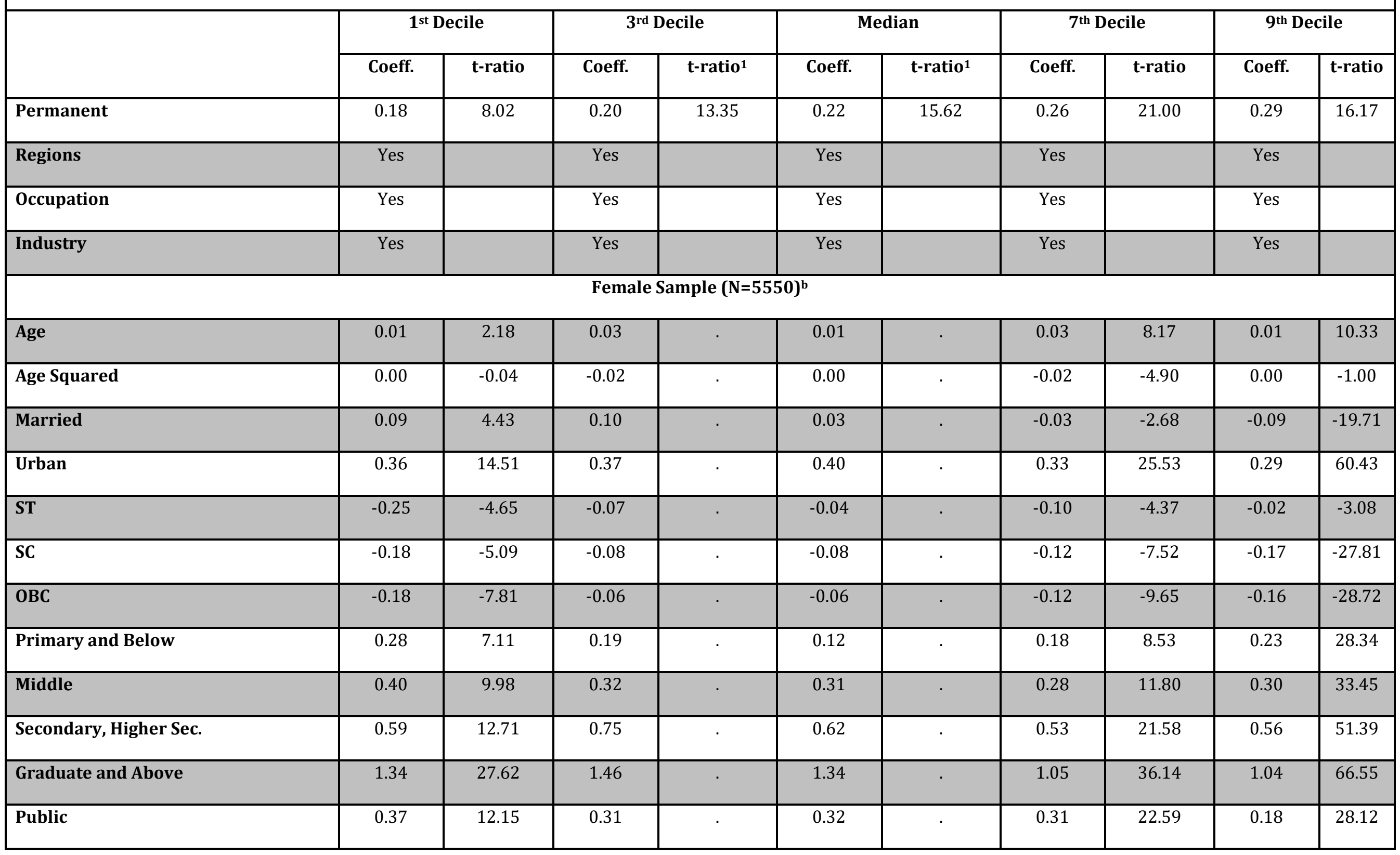




\begin{tabular}{|c|c|c|c|c|c|c|c|c|c|c|}
\hline & \multicolumn{2}{|c|}{$1^{\text {st }}$ Decile } & \multicolumn{2}{|c|}{$3^{\text {rd }}$ Decile } & \multicolumn{2}{|c|}{ Median } & \multicolumn{2}{|c|}{$7^{\text {th }}$ Decile } & \multicolumn{2}{|c|}{$9^{\text {th }}$ Decile } \\
\hline & Coeff. & t-ratio & Coeff. & t-ratio ${ }^{1}$ & Coeff. & t-ratio ${ }^{1}$ & Coeff. & t-ratio & Coeff. & t-ratio \\
\hline Union Member & 0.41 & 15.41 & 0.42 & . & 0.43 & . & 0.34 & 26.82 & 0.16 & 29.83 \\
\hline Permanent & 0.21 & 8.63 & 0.26 & . & 0.22 & . & 0.36 & 29.14 & 0.39 & 77.67 \\
\hline Occupation & Yes & & Yes & & Yes & & Yes & & Yes & \\
\hline Industry & Yes & & Yes & & Yes & & Yes & & Yes & \\
\hline
\end{tabular}

1.5 an intercept is included in all specifications. Base categories are: Illiterates for education, Others for caste.

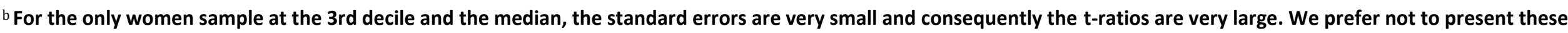
t-ratios, and not to interpret the statistical significance of these coefficients. 
Table 7: Blinder- Oaxaca Decompositions using Full Specificationa

\begin{tabular}{|c|c|c|c|c|c|c|}
\hline & \multicolumn{3}{|c|}{ 1999-2000 } & \multicolumn{3}{|c|}{$2009-2010$} \\
\hline & \multicolumn{6}{|c|}{ Alternate Counterfactuals } \\
\hline & Male & Female & Pooled & Male & Female & Pooled \\
\hline Gender Wage Gap at the Mean (in Logs) $^{b}$ & 0.42 & 0.42 & 0.42 & 0.39 & 0.39 & 0.39 \\
\hline of which Explained & 0.03 & 0.09 & 0.05 & -0.07 & 0.04 & -0.04 \\
\hline of which Unexplained & 0.39 & 0.33 & 0.37 & 0.46 & 0.34 & 0.43 \\
\hline Percent Unexplained (Discriminatory) & 92.3 & 77.8 & 88.2 & 119.1 & 88.5 & 111.1 \\
\hline Geometric Mean (INR per day) & \multicolumn{3}{|c|}{ 1999-2000 } & \multicolumn{3}{|c|}{$2009-2010$} \\
\hline Male Wage & \multicolumn{3}{|c|}{118.3} & \multicolumn{3}{|c|}{131.0} \\
\hline Female Wage & \multicolumn{3}{|c|}{77.4} & \multicolumn{3}{|c|}{88.9} \\
\hline \multicolumn{7}{|c|}{$\begin{array}{l}\text { a } 28538 \text { observations in 1999-2000 (23845 men and } 4693 \text { women) and } 31274 \text { observations in 2009-2010 (25724 men and } \\
5550 \text { women). }\end{array}$} \\
\hline
\end{tabular}




\begin{tabular}{|c|c|c|c|}
\hline \multirow[b]{2}{*}{ Decile } & \multicolumn{3}{|c|}{ Gender Wage Gaps } \\
\hline & Total & Explained & Unexplained \\
\hline \multicolumn{4}{|c|}{$1999-2000$} \\
\hline 1 & $0.77(0.03)$ & $0.04(0.02)$ & $0.73(0.01)$ \\
\hline 2 & $0.68(0.02)$ & $0.03(0.02)$ & $0.65(0.01)$ \\
\hline 3 & $0.61(0.04)$ & $0.04(0.02)$ & $0.58(0.01)$ \\
\hline 4 & $0.52(0.04)$ & $0.03(0.02)$ & $0.49(0.01)$ \\
\hline 5 & $0.43(0.05)$ & $0.03(0.02)$ & $0.40(0.01)$ \\
\hline 6 & $0.32(0.04)$ & $0.02(0.02)$ & $0.30(0.01)$ \\
\hline 7 & $0.23(0.04)$ & $0.01(0.02)$ & $0.22(0.01)$ \\
\hline 8 & $0.13(0.03)$ & $0.00(0.02)$ & $0.14(0.01)$ \\
\hline 9 & $0.08(0.03)$ & $0.00(0.02)$ & $0.08(0.01)$ \\
\hline \multicolumn{4}{|c|}{ 2009-2010 } \\
\hline 1 & $0.72(0.03)$ & $-0.01(0.03)$ & $0.74(0.01)$ \\
\hline 2 & $0.61(0.03)$ & $-0.03(0.03)$ & $0.64(0.01)$ \\
\hline 3 & $0.53(0.03)$ & $-0.06(0.02)$ & $0.58(0.01)$ \\
\hline 4 & $0.44(0.04)$ & $-0.08(0.02)$ & $0.52(0.01)$ \\
\hline 5 & $0.36(0.04)$ & $-0.09(0.02)$ & $0.45(0.02)$ \\
\hline 6 & $0.29(0.04)$ & $-0.09(0.02)$ & $0.39(0.02)$ \\
\hline 7 & $0.23(0.04)$ & $-0.10(0.02)$ & $0.33(0.02)$ \\
\hline 8 & $0.16(0.04)$ & $-0.11(0.02)$ & $0.27(0.01)$ \\
\hline 9 & $0.10(0.03)$ & $-0.10(0.02)$ & $0.20(0.02)$ \\
\hline
\end{tabular}




\begin{tabular}{|c|c|c|c|c|c|c|c|c|}
\hline \multicolumn{9}{|c|}{ Table 9 Gender Shares Among RWS Workers across Indian States ${ }^{a}$} \\
\hline & $\begin{array}{l}\text { Decadal } \\
\text { Growth }\end{array}$ & $\begin{array}{c}\text { CAGR } \\
\text { (in }\end{array}$ & \multicolumn{6}{|c|}{ Shares of RWS workers (in \%) } \\
\hline & & & \multicolumn{3}{|c|}{ 1999-2000 } & \multicolumn{3}{|c|}{$2009-2010$} \\
\hline State & & & Male & Female & $\begin{array}{c}\text { All } \\
\text { Persons }\end{array}$ & Male & Female & $\begin{array}{c}\text { All } \\
\text { Persons }\end{array}$ \\
\hline SIKKIM & 248.87 & 13.31 & 0.08 & 0.15 & 0.1 & 0.11 & 0.17 & 0.12 \\
\hline UTTARAKHAND & 206.39 & 11.85 & 0.74 & 0.78 & 0.74 & 0.89 & 0.69 & 0.86 \\
\hline CHANDIGARH & 160.85 & 10.06 & 0.29 & 0.37 & 0.3 & 0.32 & 0.41 & 0.34 \\
\hline HARYANA & 133.58 & 8.85 & 2.34 & 1.04 & 2.14 & 3.74 & 2.78 & 3.58 \\
\hline $\begin{array}{l}\text { ANDAMAN \& } \\
\text { NICOBAR }\end{array}$ & 131.47 & 8.75 & 0.08 & 0.08 & 0.08 & 0.1 & 0.14 & 0.11 \\
\hline DELHI & 127.97 & 8.59 & 4.21 & 2.88 & 4 & 3.77 & 1.97 & 3.46 \\
\hline NAGALAND & 127.22 & 8.55 & 0.14 & 0.22 & 0.15 & 0.15 & 0.09 & 0.14 \\
\hline GUJARAT & 124.33 & 8.41 & 5.79 & 4.5 & 5.59 & 7.03 & 6.04 & 6.86 \\
\hline$\overline{\text { TRIPURA }}$ & 122.09 & 8.31 & 0.25 & 0.32 & 0.26 & 0.24 & 0.36 & 0.26 \\
\hline PUDUCHERRY & 121.06 & 8.26 & 0.16 & 0.32 & 0.18 & 0.25 & 0.39 & 0.28 \\
\hline $\begin{array}{l}\text { ARUNACHAL } \\
\text { PRADESH }\end{array}$ & 110.93 & 7.75 & 0.02 & 0.01 & 0.02 & 0.1 & 0.1 & 0.1 \\
\hline MIZORAM & 108.28 & 7.61 & 0.06 & 0.11 & 0.07 & 0.1 & $\overline{0.1}$ & 0.1 \\
\hline $\begin{array}{l}\text { ANDHRA } \\
\text { PRADESH }\end{array}$ & 105.76 & 7.48 & 8.24 & 11.17 & 8.69 & 8.59 & 9.44 & 8.73 \\
\hline MAHARASHTRA & 103.48 & 7.36 & 16.74 & 14.13 & 16.33 & 16.59 & 15.11 & 16.33 \\
\hline TAMIL NADU & 102.24 & 7.30 & 10.29 & 17.16 & 11.36 & 9.39 & 12.43 & 9.92 \\
\hline KERALA & 101.85 & 7.28 & 2.86 & 7.99 & 3.66 & 3.26 & 9.09 & 4.27 \\
\hline MEGHALAYA & 91.00 & 6.69 & 0.13 & 0.33 & 0.16 & 0.24 & $\overline{0.4}$ & 0.27 \\
\hline BIHAR & 89.34 & 6.59 & 1.69 & 0.62 & 1.52 & 1.76 & 0.92 & 1.62 \\
\hline CHHATTISGARH & 88.46 & 6.54 & 1.23 & 1.04 & 1.2 & 1.42 & 1.08 & 1.36 \\
\hline
\end{tabular}




\begin{tabular}{|c|c|c|c|c|c|c|c|c|}
\hline $\begin{array}{l}\text { HIMACHAL } \\
\text { PRADESH }\end{array}$ & 88.42 & 6.54 & 0.68 & 0.57 & 0.66 & 0.82 & 0.95 & 0.84 \\
\hline$\overline{\text { ORISSA }}$ & 83.62 & 6.27 & 2.42 & 1.66 & 2.3 & 2.39 & 1.83 & 2.3 \\
\hline$\overline{\text { GOA }}$ & 81.31 & 6.13 & 0.31 & 0.38 & 0.32 & 0.5 & 0.67 & 0.53 \\
\hline WEST BENGAL & 79.64 & 6.03 & 7.01 & 5.93 & 6.84 & 6.89 & 6.47 & 6.82 \\
\hline KARNATAKA & 78.03 & 5.94 & 5.87 & 7.16 & 6.07 & 5.73 & 8.92 & 6.28 \\
\hline RAJASTHAN & 74.47 & 5.72 & 4.55 & 2.64 & 4.25 & 4.89 & 3.47 & 4.64 \\
\hline PUNJAB & 68.35 & 5.35 & 3.56 & 2.36 & 3.38 & 3.2 & 2.89 & 3.15 \\
\hline $\begin{array}{l}\text { UTTAR } \\
\text { PRADESH }\end{array}$ & 64.73 & 5.12 & 10.24 & 5.64 & 9.53 & 9.12 & 5.86 & 8.55 \\
\hline $\begin{array}{l}\text { JAMMU \& } \\
\text { KASHMIR }\end{array}$ & 59.90 & 4.81 & 0.81 & 0.48 & 0.76 & 1.1 & 0.81 & 1.05 \\
\hline$\overline{A S S A M}$ & 59.12 & 4.75 & 2.82 & 4.79 & 3.12 & 1.73 & 1.98 & 1.77 \\
\hline $\begin{array}{l}\text { MADHYA } \\
\text { PRADESH }\end{array}$ & 58.65 & 4.72 & 4.27 & 3.85 & 4.2 & 3.92 & 3.1 & 3.78 \\
\hline MANIPUR & 57.23 & 4.63 & 0.16 & 0.2 & 0.16 & 0.17 & 0.12 & 0.16 \\
\hline JHARKHAND & 52.86 & 4.33 & 1.88 & 1.07 & 1.76 & 1.39 & 1.17 & 1.35 \\
\hline Total & & & 100 & 100 & 100 & 100 & 100 & 100 \\
\hline \multicolumn{9}{|c|}{ 1.6 aStates have been arranged in order of Decadal Growth Rates (in \%). CAGR refers to Compound Annual Growth } \\
\hline
\end{tabular}


Table 10 Gender Wage Gaps among RWS workers across Indian States ${ }^{a}$

\begin{tabular}{|c|c|c|c|c|c|c|c|c|c|c|}
\hline & $\begin{array}{l}\text { Decadal } \\
\text { Growth } \\
\text { Rate (in }\end{array}$ & $\begin{array}{l}\text { CAGR } \\
\text { (in \%) }\end{array}$ & \multicolumn{6}{|c|}{ Average Wages in (in 1999-2000 Rupees per Day) } & \multicolumn{2}{|c|}{$\begin{array}{c}\text { Gender Wage } \\
\text { Gap in \% }\end{array}$} \\
\hline & & & \multicolumn{3}{|c|}{ 1999-2000 } & \multicolumn{3}{|c|}{ 2009-2010 } & $\begin{array}{l}\text { 1999- } \\
2000\end{array}$ & $\begin{array}{l}2009- \\
2010\end{array}$ \\
\hline State & & & Male & Female & $\begin{array}{c}\text { All } \\
\text { Persons }\end{array}$ & Male & Female & $\begin{array}{c}\text { All } \\
\text { Persons }\end{array}$ & & \\
\hline SIKKIM & 248.87 & 13.31 & 167.6 & 160.8 & 165.9 & 227.1 & 185.6 & 216.4 & 9.0 & $35.7^{\dagger}$ \\
\hline \begin{tabular}{|l|l} 
UTARAKHAND \\
\end{tabular} & 206.39 & 11.85 & 174.6 & 179.6 & 175.4 & 197.6 & 219.5 & 200.6 & 1.4 & 15.3 \\
\hline CHANDIGARH & 160.85 & 10.06 & 184.0 & 210.5 & 189.0 & 337.5 & 215.3 & 311.5 & $\begin{array}{l}-6.7 \\
\end{array}$ & $100.3^{* *}$ \\
\hline HARYANA & 133.58 & 8.85 & 175.1 & 181.5 & 175.6 & 164.1 & 161.9 & 163.8 & 11.1 & $36.0^{+}$ \\
\hline $\begin{array}{l}\text { ANDAMAN \& } \\
\text { NICOBAR }\end{array}$ & 131.47 & 8.75 & 169.6 & 167.3 & 169.2 & 297.0 & 235.2 & 282.6 & 1.3 & $36.0^{*}$ \\
\hline $\begin{array}{l}\text { DELHI } \\
\end{array}$ & 127.97 & 8.59 & 269.8 & 274.3 & 270.3 & 198.7 & 202.2 & 199.0 & 1.6 & 6.1 \\
\hline NAGALAND & 127.22 & 8.55 & 188.0 & 171.0 & 184.3 & 256.8 & 214.9 & 252.2 & 12.2 & 14.2 \\
\hline GUJARAT & 124.33 & 8.41 & 164.1 & 151.2 & 162.5 & 167.1 & 135.0 & 162.2 & $27.2^{*}$ & $42.4^{* *}$ \\
\hline TRIPURA & 122.09 & 8.31 & 145.7 & 126.1 & 142.0 & 187.9 & 165.5 & 182.6 & 27.1 & 23.6 \\
\hline PUDUCHERRY & 121.06 & 8.26 & 129.7 & 111.9 & 124.9 & 230.7 & 178.8 & 217.8 & $74.7^{* *}$ & $63.6^{* *}$ \\
\hline $\begin{array}{l}\text { ARUNACHAL } \\
\text { PRADESH }\end{array}$ & 110.93 & 7.75 & 217.7 & 146.4 & 210.8 & 362.9 & 260.2 & 344.5 & 32.5 & $39.1^{* *}$ \\
\hline MIZORAM & 108.28 & 7.61 & 244.9 & 248.6 & 245.8 & 241.8 & 266.6 & 246.2 & 0.3 & -7.4 \\
\hline $\begin{array}{l}\text { ANDHRA } \\
\text { PRADESH }\end{array}$ & 105.76 & 7.48 & 134.9 & 84.5 & 124.9 & 161.2 & 101.7 & 150.0 & $89.7^{* * *}$ & $81.8^{* * *}$ \\
\hline MAHARASHTRA & 103.48 & 7.36 & 160.7 & 142.6 & 158.3 & 212.0 & 207.0 & 211.2 & $31.1^{* * *}$ & $24.1^{*}$ \\
\hline TAMIL NADU & 102.24 & 7.30 & 130.6 & 101.7 & 123.8 & 182.6 & 144.3 & 174.2 & $59.1^{* *}$ & $48.4^{* *}$ \\
\hline KERALA & 101.85 & 7.28 & 153.4 & 112.4 & 139.5 & 220.6 & 160.4 & 198.4 & $62.2^{* * *}$ & $55.0^{* * *}$ \\
\hline MEGHALAYA & 91.00 & 6.69 & 182.5 & 162.7 & 176.3 & 211.6 & 199.7 & 208.5 & 19.3 & 12.0 \\
\hline BIHAR & 89.34 & 6.59 & 165.1 & 181.9 & 166.2 & 173.7 & 218.3 & 178.2 & -19.0 & -15.8 \\
\hline CHHATTISGARH & 88.46 & 6.54 & 166.8 & 102.1 & 158.1 & 217.6 & 92.3 & 200.3 & $106.6^{* *}$ & $154.3^{* * *}$ \\
\hline
\end{tabular}




\begin{tabular}{|c|c|c|c|c|c|c|c|c|c|c|}
\hline $\begin{array}{l}\text { HIMACHAL } \\
\text { PRADESH }\end{array}$ & 88.42 & 6.54 & 195.5 & 169.9 & 192.1 & 246.1 & 172.6 & 231.7 & $32.7^{\dagger}$ & 85.9 *** \\
\hline ORISSA & 83.62 & 6.27 & 147.3 & 114.9 & 143.7 & 197.4 & 129.4 & 188.0 & $46.0^{*}$ & $85.9^{* * *}$ \\
\hline GOA & 81.31 & 6.13 & 174.4 & 134.1 & 167.0 & 160.1 & 131.4 & 153.7 & $38.9 *$ & $35.4^{\dagger}$ \\
\hline WEST BENGAL & 79.64 & 6.03 & 158.4 & 102.9 & 150.9 & 176.8 & 122.2 & 167.8 & $89.1^{* * *}$ & $72.4^{* * *}$ \\
\hline KARNATAKA & 78.03 & 5.94 & 151.3 & 114.1 & 144.5 & 202.5 & 131.1 & 184.9 & $49.6^{* * *}$ & $99.0^{* * *}$ \\
\hline RAJASTHAN & 74.47 & 5.72 & 151.5 & 137.8 & 150.1 & 180.1 & 136.5 & 174.4 & 21.3 & $66.7^{* *}$ \\
\hline PUNJAB & 68.35 & 5.35 & 138.9 & 171.6 & 142.5 & 171.5 & 169.0 & 171.1 & -0.8 & $37.2^{*}$ \\
\hline UTTAR PRADESH & 64.73 & 5.12 & 143.2 & 94.2 & 138.7 & 169.1 & 130.1 & 164.4 & $97.2^{* * *}$ & $51.3^{* *}$ \\
\hline $\begin{array}{l}\text { JAMMU \& } \\
\text { KASHMIR }\end{array}$ & 59.90 & 4.81 & 186.7 & 185.2 & 186.6 & 203.4 & 199.7 & 202.9 & 21.8 & 20.2 \\
\hline ASSAM & 59.12 & 4.75 & 126.8 & 71.7 & 113.7 & 218.4 & 96.2 & 194.7 & $65.5^{* * *}$ & $147.2^{* * *}$ \\
\hline $\begin{array}{l}\text { MADHYA } \\
\text { PRADESH }\end{array}$ & 58.65 & 4.72 & 134.2 & 103.8 & 129.9 & 146.1 & 131.9 & 144.1 & $39.9 *$ & 4.1 \\
\hline$\overline{\text { MANIPUR }}$ & 57.23 & 4.63 & 194.1 & 203.2 & 195.8 & 236.4 & 236.3 & 236.4 & -9.7 & 10.1 \\
\hline JHARKHAND & 52.86 & 4.33 & 191.3 & 141.6 & 186.5 & 220.7 & 103.5 & 203.0 & $48.5^{*}$ & $160.4^{* * *}$ \\
\hline $\begin{array}{l}\text { aStates have } \\
\text { indicates sig }\end{array}$ & anco & $*$ & ? & irowth & $\%$ & R r & Con & Ann & owth (in & $\%) .+$ \\
\hline
\end{tabular}

